\title{
Permeability and hydraulic conductivity of faulted micaschist in the eastern Elba Island exhumed geothermal system (Tyrrhenian sea, Italy): insights from Cala Stagnone
}

\author{
Martina Zucchi ${ }^{\mathrm{a}, *}$, Andrea Brogi ${ }^{\mathrm{a}}$, Domenico Liotta ${ }^{\mathrm{a}, \mathrm{c}}$, Valentina Rimondi ${ }^{\mathrm{b}}$, Giovanni Ruggieri ${ }^{\mathrm{b}}$, \\ Giordano Montegrossi ${ }^{\mathrm{b}}$, Alfredo Caggianellia ${ }^{\mathrm{a}}$, Andrea Dini ${ }^{\mathrm{c}}$ \\ ${ }^{a}$ University of Bari, Department of Earth and Geoenvironmental Sciences, Via Orabona, 4, Bari, Italy \\ ${ }^{\mathrm{b}}$ IGG-CNR, Institute of Geosciences and Earth Resources, Via G. La Pira, 4, Firenze, Italy \\ ${ }^{\mathrm{c}}$ IGG-CNR, Institute of Geosciences and Earth Resources, Via Moruzzi, 1, Pisa, Italy
}

\section{A R T I C L E I N F O}

\section{Keywords:}

Geothermal reservoir

Analogue

Exhumed geothermal system

Micaschist

Elba Island

\begin{abstract}
A B S T R A C T
Estimating values of permeability $(\mathrm{k})$, efficient porosity $(\mathrm{P})$ and hydraulic conductivity $(\mathrm{K})$ by analysing field outcrops as analogue of geothermal reservoirs, is a timely theme useful for predictions during geothermal exploration programs. In this paper we present a methodology providing $\mathrm{k}, \mathrm{P}$ and $\mathrm{K}$ values, based on geometric analysis of quartz-tourmaline faults-vein arrays hosted in micaschist exposed in south-eastern Elba Island (Tuscan Archipelago, Italy), considered as the analogue of rock hosting the so-called "deep reservoir" in the Larderello geothermal field. The methodology is based on the integration among structural geology, fluid inclusions results and numerical analyses. Through a detailed structural mapping, scan-lines and scan-boxes analyses, we have reconstructed three superposed faulting events, developed in an extensional setting and framed in the Neogene evolution of inner Northern Apennines. Geometrical data of the fault-veins array were processed by reviewing the basic parallel-plate-model-equation for k evaluation. Fluid inclusion analyses provided those salinity values necessary for defining density and viscosity of the parent geothermal fluids. Then, permeability, density and viscosity were joined to get hydraulic conductivity (K). Permeability is estimated between $5 \times 10^{-13}$ and $5 \times 10^{-17} \mathrm{~m}^{2}$ with variations among the different generation of faults, while the hydraulic conductivity is encompassed between $1.31 \times 10^{-8}$ and $2.4 \times 10^{-13} \mathrm{~m} / \mathrm{s}$. The obtained permeability and hydraulic conductivity values are comparable with those from several geothermal areas, and in particular from the Larderello geothermal field. The main conclusion is that the proposed integrated approach provides a reliable methodology to obtain crucial values, normally obtained after drilling, for developing numerical flow models of geothermal fluid path in active geothermal systems by field and laboratory analyses of analogue, exhumed, geothermal systems.
\end{abstract}

\section{Introduction}

Hydraulic properties of rock volumes, in terms of permeability (k), hence efficient porosity $(\mathrm{P})$ and hydraulic conductivity $(\mathrm{K})$ are parameters describing the ability of the rock volume to channel fluids at crustal depth, where primary porosity is negligible and fluid flow is controlled by fracture networks (Sibson, 2000; Rowland and Sibson, 2004; Faulkner et al., 2010; for a review). Determination of such parameters and their variation through time are fundamental issues for both exploration and exploitation of geothermal reservoirs. These are fundamental features to estimate the potentiality of a geothermal sys- tem and, consequently, to calibrate the investments and the economic plans (Barbier, 2002).

Hydraulic properties of reservoirs can be directly measured in laboratories (e.g.: Preisig et al., 2015; Milsch et al., 2016) and/or extrapolated through boreholes tests (e.g.: Peters, 2012; Stober and Bucher, 2014, 2015). The main results highlight that, in general, the permeability ( $k$ ) decreases with depth, following an almost linear law, as documented in several geothermal fields (Stober and Bucher, 2007), even though local inversions may be found when rock volumes with different mechanical properties are encountered.

Permeability values in active geothermal areas have been directly measured in the range of $10^{-21}-10^{-12} \mathrm{~m}^{2}$ at depth (Stober and

\footnotetext{
* Corresponding author.

Email address: martina.zucchi@uniba.it (M. Zucchi)
} 
Bucher, 2014 with references therein), although reservoir rocks display permeability commonly encompassed between $10^{-14}$ and $10^{-17} \mathrm{~m}^{2}$ (Rowland and Sibson, 2004). Nevertheless it is demonstrated that permeability values are transient (Cox et al., 2001), being controlled by the interplay between tectonic activity (Sibson, 1987; Cox, 1999; Curewitz and Karson, 1997; Rowland and Sibson, 2004; Uysal et al., 2009) and fluid/rock interaction (Fyfe, 1987; Polak et al., 2003; Uysal et al., 2009; Alt-Epping et al., 2013). Generally, these two processes play in opposite directions: the former enhancing permeability, the latter sealing the fractures when precipitation of hydrothermal minerals occurs.

These opposite processes may coexist and/or occur in several repeated cycles implying that permeability in geothermal systems is overall time-dependent (Curewitz and Karson, 1997; Cox et al., 2001; Uysal et al., 2011; Brogi et al., 2012; Brogi et al., 2016). However, permeability evolution through time cannot be recorded by boreholes tests able only to estimate the Present condition.

Generally, in hydrocarbon studies, determination of the hydraulic parameters of rock masses are derived from conventional 2D or 3D reservoir simulators (Long and Witherspoon, 1985; Cacas et al., 1990; Odling, 1992; Massonnat and Manisse, 1994; Lough et al., 1997; Bourbiaux et al., 1998; Min et al., 2004), whereas information on fracture array derives from fractal analyses (Miao et al., 2015 with references therein) and/or analyses of fracture data collected on analogue, exhumed, rock reservoirs (e.g.: Hausegger et al., 2009; Agosta et al., 2010; Kim and Sanderson, 2010). It is therefore accepted that the results obtained from exposed outcrops can be considered representative even for rock volumes located at depth, although boundary conditions are different. Thus a statistical and/or numerical approach (Lisjak and
Grasselli, 2014 with references therein) is commonly applied to foresee the distribution of fractures at depth.

Differently, in analogue, exhumed, geothermal systems, the fracture array that was present during fluid circulation is now defined by veins filled with hydrothermal minerals, indicating the original path through which fluids were channelled at the time and depth of their flow (McCaffrey et al., 1999).

In this paper we describe a methodological approach, based on geometrical analyses of hydrothermal (tourmaline-quartz) veins hosted in micaschist belonging to the eastern Elba Island exhumed geothermal system (Fig. 1), and referred to the development of different faults generations. This area is considered the analogue of the about 4-5 km deep reservoir in micaschist presently exploited in the Larderello geothermal system (Batini et al., 2003; Bellani et al., 2004; Romagnoli et al., 2010).

The evolution of the hydrothermal veins, in terms of their spatial distribution (array) and growth through time, was defined by a detailed examination of their crosscutting relationships, mainly based on geometrical analyses through scan-line and scan-box methodologies applied in selected outcrops, and by mineralogical and fluid inclusion studies. Reassessing the base algorithm for the permeability estimation (Gale, 1982; Cox et al., 2001), the maximum permeability values of the micaschist palaeo-geothermal reservoir have been calculated through time. Jointly, permeability values and pressure-temperature-salinity parameters derived from the fluid inclusion data, have been considered as the key-parameters to estimate the paleo-fluids viscosity, therefore contributing to better constrain several key chemical-physical parameters characterising the paleo-geothermal field now exposed in the eastern Elba Island. The main results highlight the considerable role of fluctu-

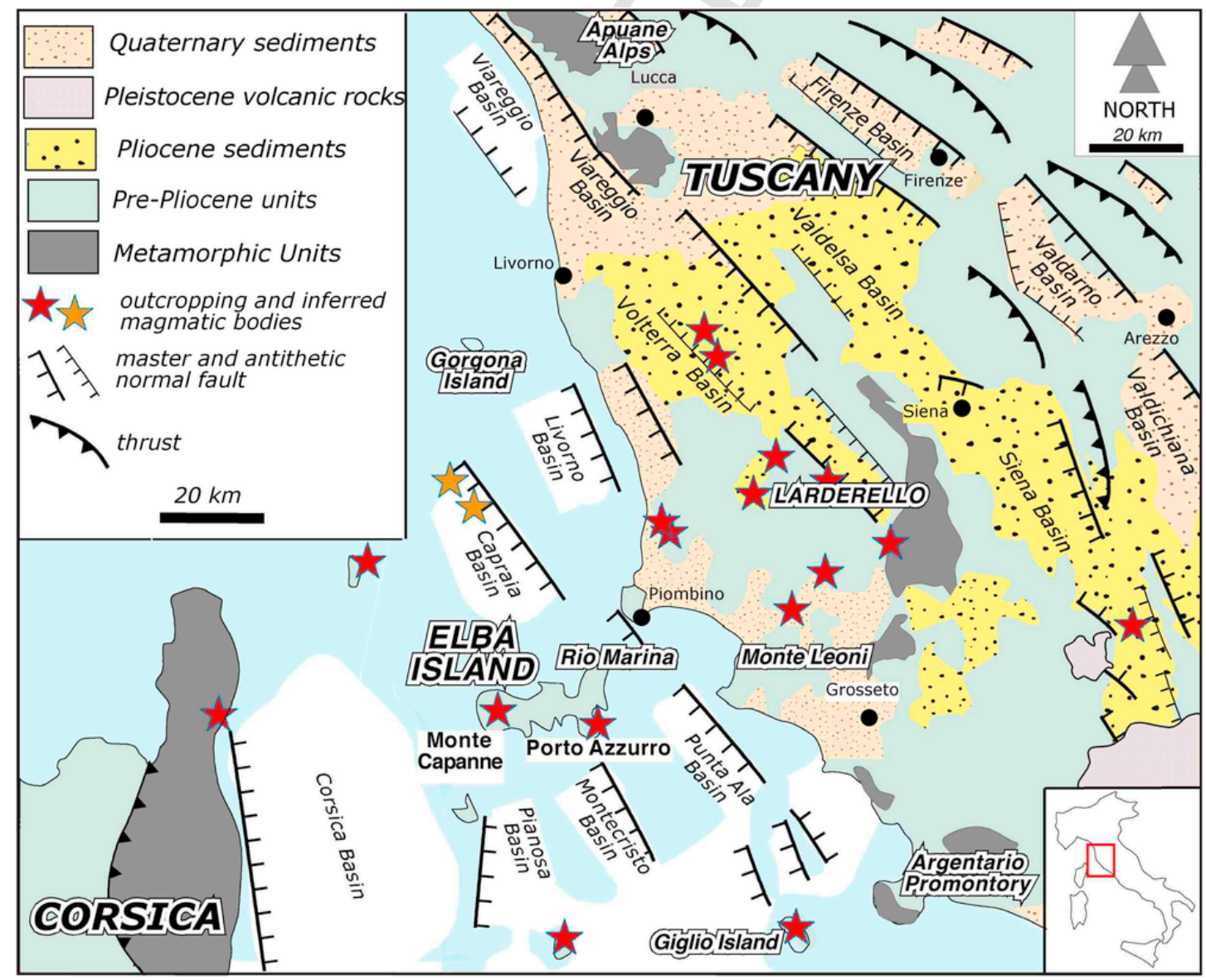

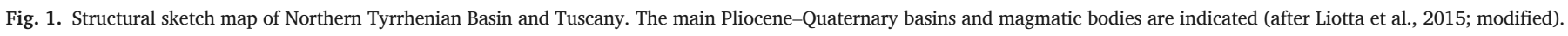


ant fluid pressure in maintaining the permeability within the reservoir. Furthermore, permeability and hydraulic conductivity of the micaschist reservoir estimated for the eastern Elba Island are comparable with those measured in the Larderello geothermal field.

\section{Geological setting}

The Elba Island (Tuscan Archipelago, Fig. 1) is part of the Northern Apennines inner zone. Northern Apennines is an alpine collisional belt (Cretaceous-Early Miocene) deriving from the convergence and subsequent collision between the Adria microplate, representing the Africa plate, and the Sardinia-Corsica Massif of European pertinence (Molli, 2008 for a review). Collision determined the stacking and doubling of oceanic and continental tectonic units deriving from the palaeo-geographic domains of the Northern Apennines (Carmignani et al., 1994; Bianco et al., 2015). Since early-middle Miocene, inner Northern Apennines has been affecting by eastwards migrating extensional tectonics that can be described through two main events (Brogi and Liotta, 2008; Barchi, 2010): (a) the first one (early to late Miocene), characterized by an extension of at least $120 \%$ (Carmignani et al., 1994; Liotta et al., 1998; Brogi, 2006), gave rise to low-angle normal faults; this event produced the lateral segmentation of the previously stacked tectonic units and the exhumation of mid-crustal rocks (Liotta et al., 1998; Brogi, 2008; Barchi, 2010); (b) the second event (Pliocene to Present) is differently defined by high angle normal faults, cross-cutting the previous structures, and determining tectonic depressions where Pliocene to Quaternary continental and marine sediments deposited (Martini and Sagri, 1993). The amount of extension is here estimated in about
6-7\% (Carmignani et al., 1994). The opening of the Tyrrhenian basin and the present crustal and lithospheric thicknesses; (20-22 and 30-50 km, respectively in: Calcagnile and Panza, 1981; Locardi and Nicolich, 1992), are the clearest evidence of the extensional setting.

Since Langhian, the migration of extension is accompanied by magmatism, with an eastward younging direction (Fig. 1), mostly deriving from mixing of crustal and mantle sources (Serri et al., 1993; Peccerillo, 2003). Cooling of late Miocene-Pliocene plutons (such as the Monte Capanne and Porto Azzurro magmatic complexes at Elba Island, Westerman et al., 2004; Caggianelli et al., 2014) determined a widespread epithermal and mesothermal mineralization through Tuscany and Elba Island (Dini, 2003), where ore deposits were exploited for centuries (Fig. 1).

Hence, the high heat flow of Tuscany (regionally above $100 \mathrm{~mW} / \mathrm{m}^{2}$ with local peaks up to $1 \mathrm{~W} / \mathrm{m}^{2}$, Mongelli and Zito, 1991; Della Vedova et al., 2001) and the presently exploited Larderello and Monte Amiata geothermal fields find a common explanation in this long-lasting active extensional and magmatic framework (Batini et al., 2003).

Thus, in the frame of the eastward extensional and magmatic migration, Elba Island (Fig. 2) is considered a precursor of the present Larderello geothermal system on the basis of the similarities in the geological settings (Trevisan, 1950; Puxeddu, 1984; Bortolotti et al., 2001), magmatic and tectonic evolution (Garfagnoli et al., 2005; Dini et al., 2005).

Furthermore, the structurally deepest rocks of Elba Island are micaschist affected by low-P metamorphism, crosscut by leucogranite dykes (Garfagnoli et al., 2005; Musumeci et al., 2011) and quartz-tour-

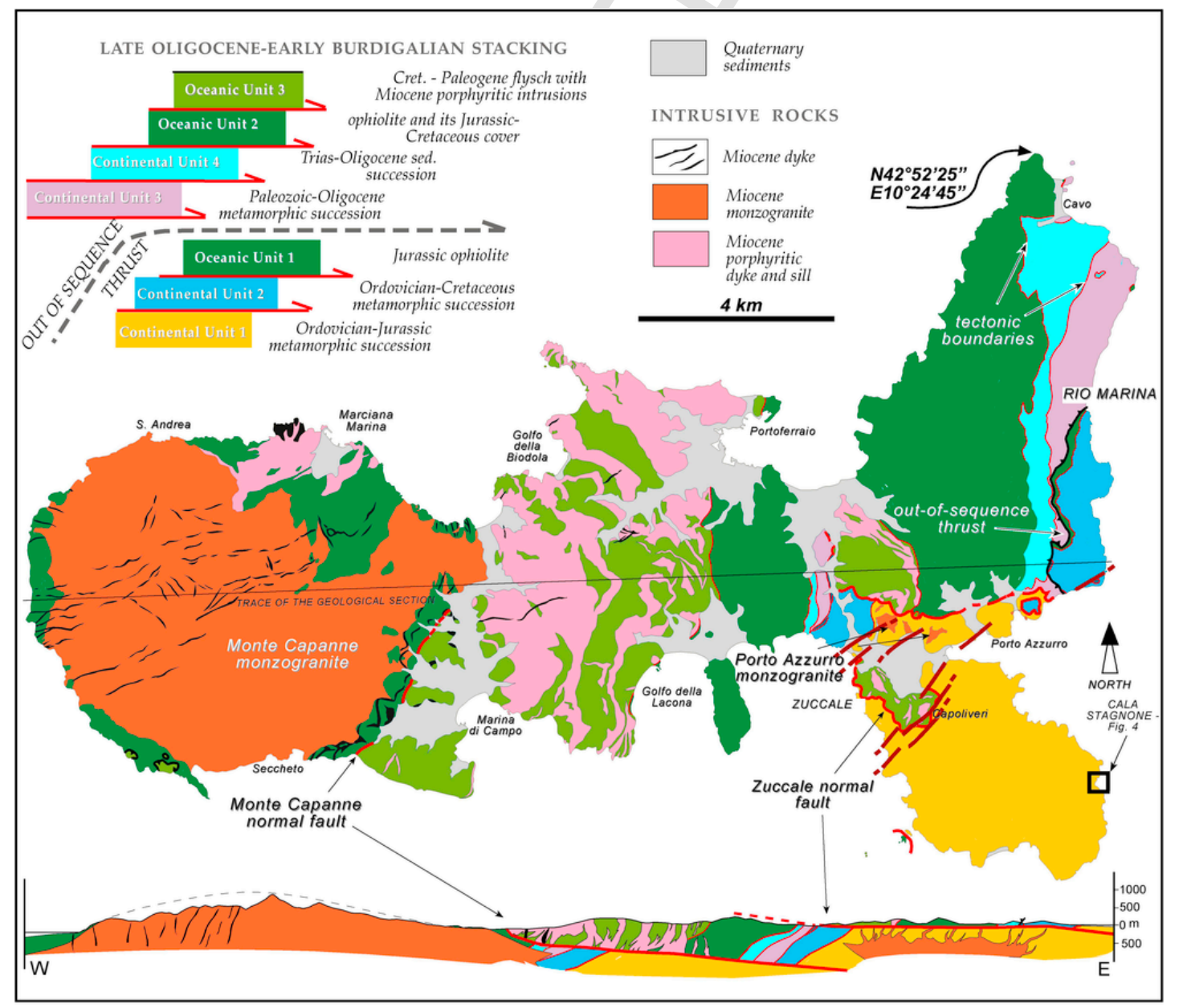

Fig. 2. Geological sketch map of Elba Island. The main low-angle and high-angle faults are highlighted (after Liotta et al., 2015; Bianco et al., 2015). 
maline veins (Dini et al., 2008; Viti et al., 2016). These features can be compared with the metamorphic basement drilled at depth $(3.5-5 \mathrm{~km}$ b.g.1.) in Larderello, where micaschist with overpressured B-rich saline fluids (Cavarretta et al., 1993) were drilled at about $3 \mathrm{~km}$ depth.

Low-P micaschist (Garfagnoli et al., 2005) is widely exposed in the Monte Calamita Promontory (Fig. 2). This represents the host-rock of the Porto Azzurro monzogranite (5.9-5.4 Ma, Maineri et al., 2003), whose cooling was accompanied by the activity of a significant hydrothermal system, now exposed in the eastern side of Elba Island. This is testified by the notable variety of hydrothermal parageneses (Dini, 2003). Differently, the hydrothermal system connected to the western and older Monte Capanne plutonic complex (8-6.8 Ma, in: Dini et al., 2002; Fig. 2) is almost completely eroded.

\section{Rock fabric}

The Monte Calamita micaschist derives from a pelitic protholith of Cambrian to Ordovician age (Musumeci et al., 2011; Sirevaag et al., 2016). It is intruded by tourmaline-rich leucogranite dykes (Fig. 3a) and quartz-tourmaline veins, the latter related to the cooling stage of the Porto Azzurro monzogranite (Barberi et al., 1967; Dini et al., 2008). Micaschist is characterized by a NE-dipping main schistosity (Fig. 3a), defined by quartz ribbons and interlayered biotite rich-levels (Fig. 3b).

The syn-kinematic mineralogical assemblage defining the main schistosity is given by $\mathrm{Qtz}+\mathrm{Bt} \pm \mathrm{Ab}$ (Fig. 3c-d). This foliation is overprinted by syn- to post-kinematic LP paragenesis, consisting of $\mathrm{Qtz}+\mathrm{Ms}+\mathrm{Bt}+$ And \pm Crd \pm Ttn (Fig. 3e-f). Duranti et al. (1992) estimated a peak temperature of $650{ }^{\circ} \mathrm{C}$ at pressure of about $2 \mathrm{Kbar}$,
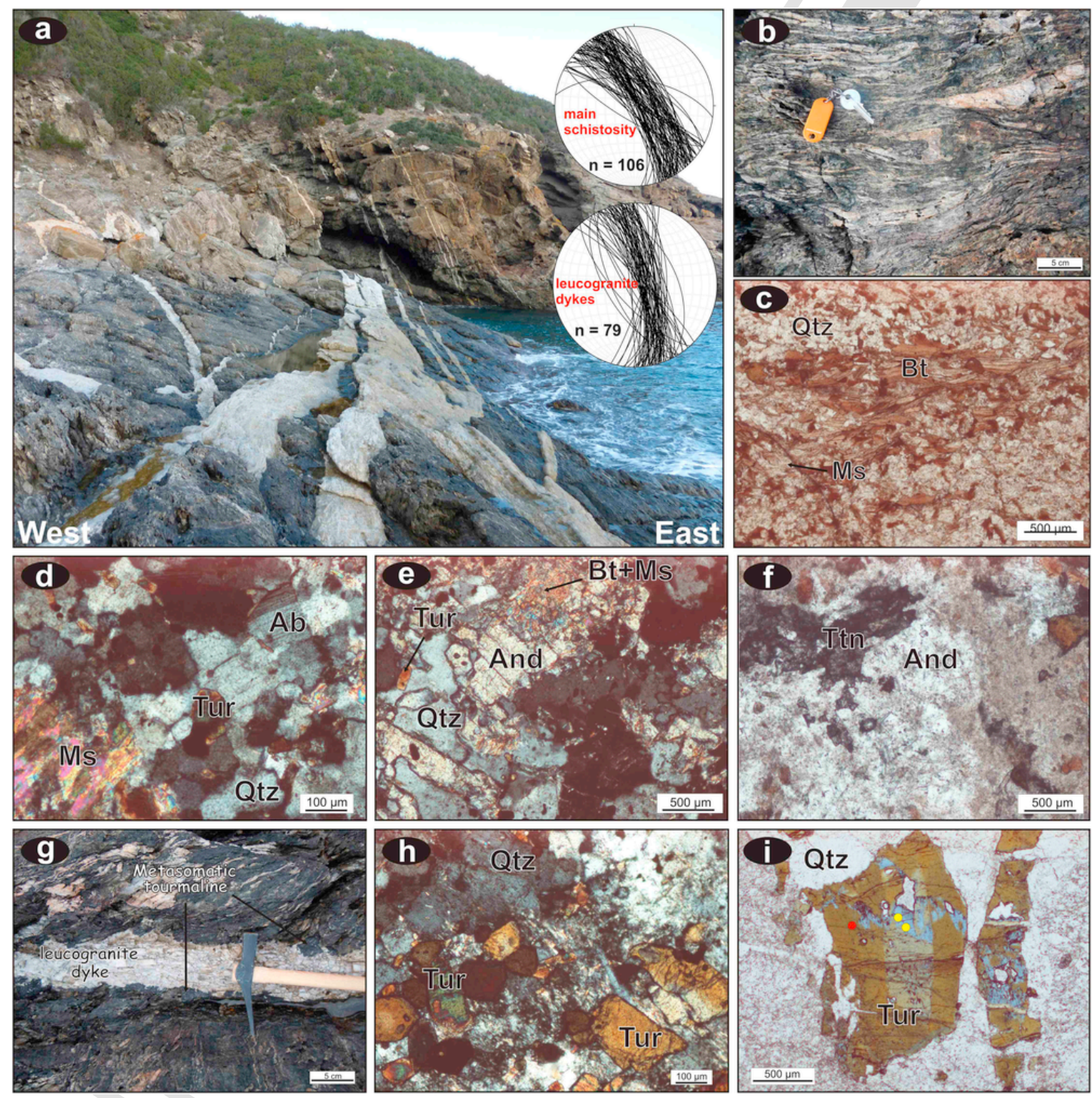

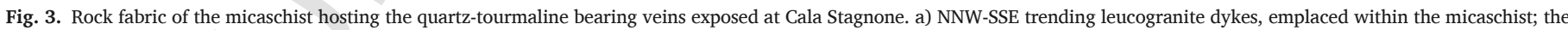

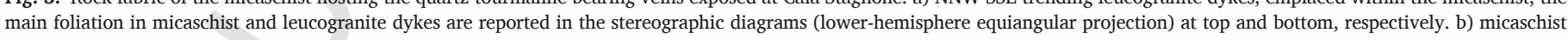

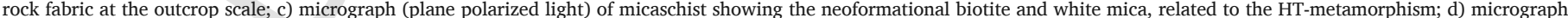

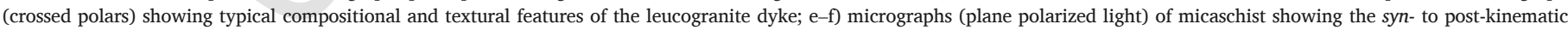

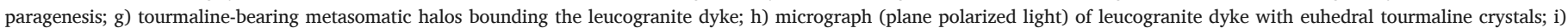

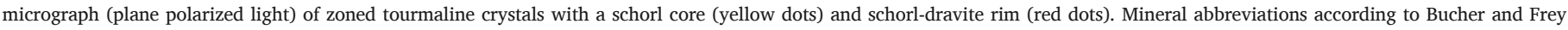
(1994). (For interpretation of the references to colour in this figure legend, the reader is referred to the web version of this article.) 
dated by Musumeci et al. (2011) at about 6.2 Ma on the basis of U/Pb method on Zircon rims and of ${ }^{40} \mathrm{Ar} /{ }^{39} \mathrm{Ar}$ method on muscovite.

The leucogranite dykes range from few centimeters to $1 \mathrm{~m}$ in thickness. They are generally characterized by sub-vertical attitude (Fig. 3a and $\mathrm{g}$ ) and emplaced at low angle with respect to the main schistosity of the wall rock. Leucogranite dykes consist of K-feldspar, quartz, muscovite, biotite and tourmaline, mainly of schorl-dravite composition (Fig. 3h-i). Centimeters-thick metasomatic rims and patches affect the micaschist close to the dyke-walls and along the main foliation, where the biotite-rich levels (Fig. 3g) have been partially or completely replaced by tourmaline (Dini et al., 2008). Both dykes and micaschist are crosscut by low- and high-angle faults. The related slip-zones hosted mineralizing fluids that deposited syn-kinematic tourmaline (dravite to uvite, Dini et al., 2008). The high-angle faults systematically cross-cut the low-angle ones. A third generation of sub-vertical, mostly thin, fault slip zones are mineralized almost entirely by quartz. The different fault generations are described in the following.

\section{Methodological approach and data analyses}

In order to get parameters useful to define permeability, porosity and hydraulic conductivity from field and laboratory data, we developed a methodological approach based on: (a) geological survey and fluid inclusion analyses; (b) detailed geological mapping in key areas and collection of geometrical parameters (length and width of fractures) through scan-lines and scan-boxes; (c) estimation of permeability from the collected structural data; (d) estimation of fluid density and viscosity from fluid inclusion data, and, finally (e) hydraulic conductivity, considering the results from each of the previously listed steps. In the following, data related to each passage are described in different sections.

\subsection{Faults}

The geological survey of the study area (Fig. 4a) highlighted three generations of mineralized fault-slip zones (Fig. 4b) with different trends, structural and textural features. Their cross-cutting relationships have been defined at the outcrop scale.

The older mineralized fault system (hereafter 1st faults generation) is defined by low-angle slip-zones (B-Vein, in Dini et al., 2008; Fig. $4 \mathrm{c}-\mathrm{d}$ ), consisting of $1-40 \mathrm{~cm}$ thick cataclasite (Fig. 4d) cemented by tourmaline and minor quartz (Fig. 4e-f). Tourmaline cement is generally fine-grained $(100-500 \mu \mathrm{m})$ with few crystals showing a euhedral or sub-euhedral habitus. Coarse-grained cataclastic elements are constituted of angular fragments of host rock and early tourmaline vein infill. Quartz is present in the veins as minor phase generally occurring as roundish grains, highly fractured, dispersed in tourmaline cement, or as anhedral crystal aggregates of cataclastic nature (Dini et al., 2008). In some parts, the cataclasite derived from hydrofracturing processes together with shearing (Fig. 4g-i), thus suggesting the generation of overpressured fluids during deformation.

The boundary of the cataclasite consists of polished surfaces where tourmaline fibers can be locally recognised, attesting their syn-kinematic crystallization. Furthermore, mechanical striations on tourmaline cataclasite suggest that fault activity continued even after the tourmaline crystallization (Fig. $4 \mathrm{j}-\mathrm{k}$ ).

Stereographic diagrams (Fig. 4b) indicate that a minority of fault-slip zones dip to the E, thus defining a lozange-shaped network with rhomboid lithons characterized by their main diagonal up to $2 \mathrm{~m}$ long (Fig. 5a). Kinematics is mainly defined by oblique-slip to normal movements for both $\mathrm{E}$ and W dipping faults (Fig. 5a).

These low-angle faults are also characterized by splay fractures (A-Vein, in: Dini et al., 2008), still filled by quartz and tourmaline (Fig. 5b-f). The 1st faults generation, however, systematically cross-cuts the leucogranite dykes (Figs. c-d), possibly developed in P-T conditions close to those of the thermometamorphic event (Duranti et al., 1992).

The high-angle fault-slip zones (hereafter 2nd faults generation, Fig. 6a-b) consist of $0.1-5 \mathrm{~cm}$ thick greenish to brownish cataclasite (Fig. $6 c-f$ ) with mainly quartz and micaschist clasts (up to $5 \mathrm{~mm}$ ), mainly cemented by very fine-grained green tourmaline, minor quartz and small amount of Fe-sulphide. In some cases, tourmaline is distributed along the fault surface, especially when the fault crosscuts the tourmaline-bearing leucogranite dykes (Fig. 6 g). These faults show a NNW-SSE trending and a subvertical attitude (Fig. 4b). In few cases right-lateral oblique-slip kinematic indicators, consisting of quartz-tourmaline fibers and mechanical striations, have been recognised on their slip-surfaces. Splays at low-angle $\left(20-40^{\circ}\right)$ to the main slip zone are discontinuously distributed in the damage zones, although coherent with the right-lateral movement (Fig. 6e-f).

The 3rd faults generation consists of sub-vertical SSW-NNE fault-slip zones (Fig. 4b) characterized by $1-10 \mathrm{~cm}$ thick quartz cataclasite (Fig. 7a-b) and SW-NE trending splays, mainly consisting of quartz veins (Fig. 7c), ranging from $1 \mathrm{~mm}$ to $1 \mathrm{~cm}$ in thickness (Fig. 7a). The width of the splay structures is variable at the outcrop scale (Fig. $7 \mathrm{~d}-\mathrm{f}$ ), resulting pervasive $(0.2-1 \mathrm{~m}$ spaced) or absent. In few cases right-lateral oblique-slip kinematic indicators, consisting of quartz fibers, have been recognised.

\subsection{Fluid inclusions}

Hydraulic conductivity computation requires the knowledge of the viscosity of the fluid that flowed in the fractures. Fluid inclusion analyses can provide clue parameters (i.e., fluid density, salinity, temperature and pressure) needed for the calculation of viscosity. Preliminary data on fluid inclusions trapped in quartz occurring in quartz-tourmaline veins at Cala Stagnone are reported in Rimondi et al. (2015a, 2015b) and Zucchi et al. (2016). However, quartz is a minor phase in such veins, thus, in order to estimate the viscosity of the fluid(s) that has circulated longer and that formed and/or interacted with tourmaline, we focused on fluid inclusions in tourmaline occurring in 1st and 2nd faults generations. In addition, fluid inclusions were examined in quartz of the 3rd faults generation.

Because of its relatively poor optical features and fine-grained nature, very few inclusions were observed within tourmaline. All these inclusions were found in larger crystals belonging to the 1st faults generation, only. Fluid inclusions occurred as isolated exemplars or grouping in 2-3 individuals, and ranging from 5 to $20 \mu \mathrm{m}$ in dimensions (Fig. 8a and b). Petrographic observations indicated that many fluid inclusions were open to the surface (dark fluid inclusions), and that some inclusions have been affected by necking down (Roedder, 1984). These inclusions were not considered for microthemometric analyses.

Differently, no fluid inclusions were observed in tourmaline of the 2nd faults generation, probably due to their low dimensions, not discernible at the optical microscope.

Many fluid inclusions, suitable for microthermometry, were observed in quartz of the 3rd faults generation. Here, fluid inclusions may group together in many individuals (Fig. 8c and d), ranging from 5 to $50 \mu \mathrm{m}$, displaying a tridimensional or along specific planes distribution.

In tourmaline of the 1 st faults generation and in quartz of the 3rd faults generation, phase assemblage at room temperature divided fluid inclusions in two typologies (Fig. 8a d): i) liquid-rich inclusions (L), displaying quite a variable $\mathrm{L} / \mathrm{V}$ ratio (from 30 to $50 \%$ ), and ii) multiphase inclusions (S), containing halite and sometimes other 1-2 solids. One of this solid in quartz was recognised as hematite (Fig. 8d). Both L and S inclusions (and related solids other than halite) were also 

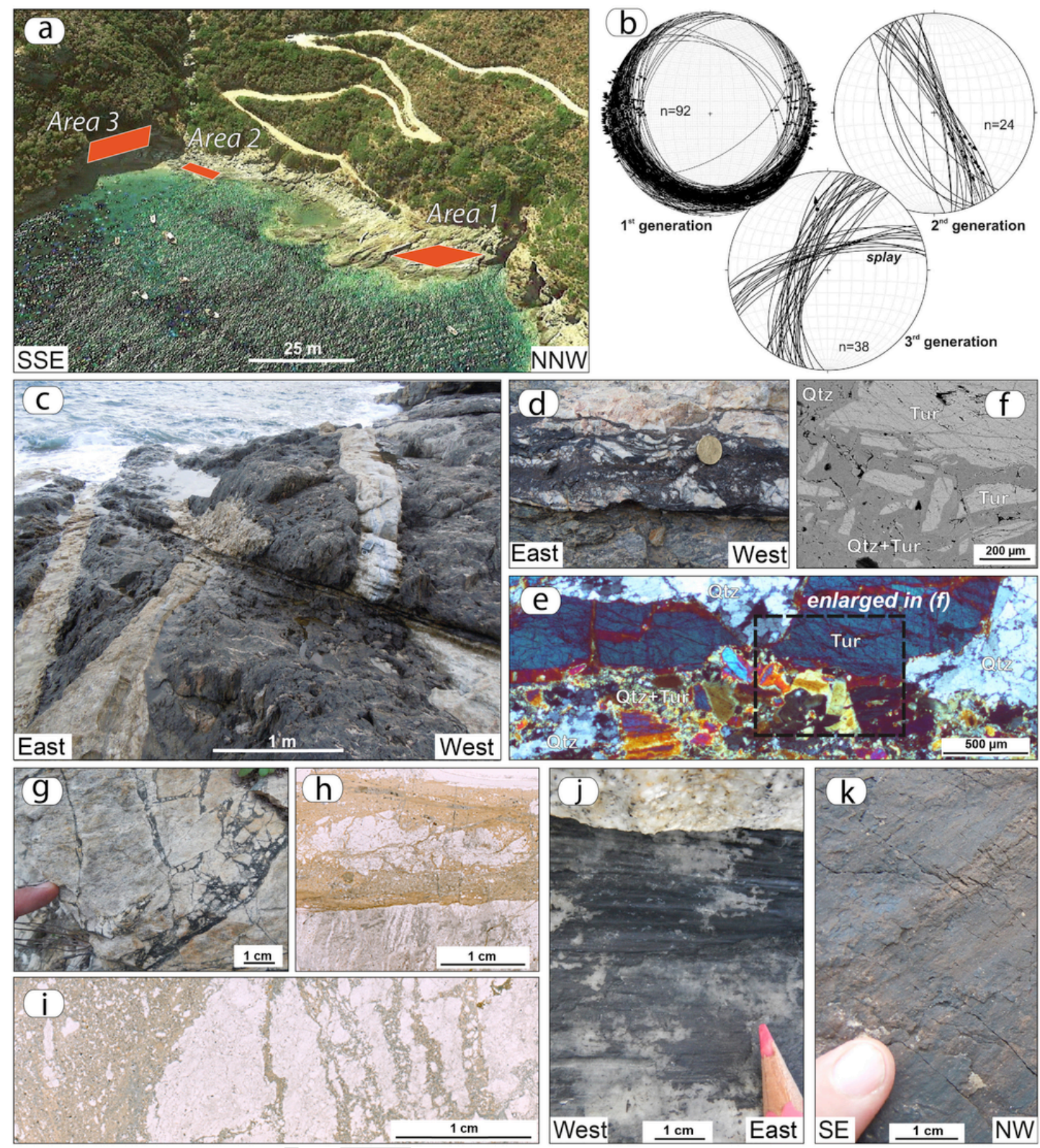

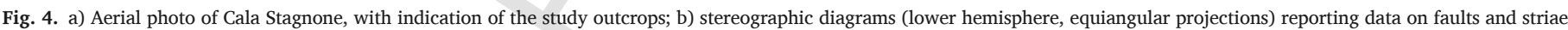

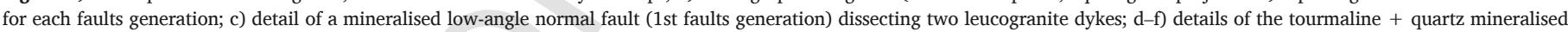

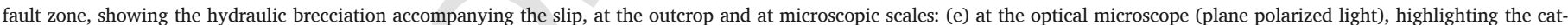

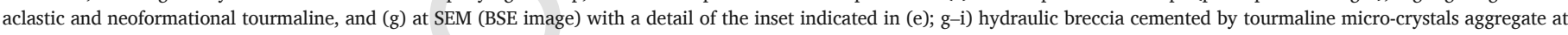

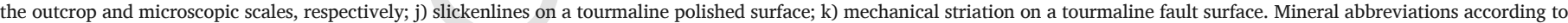
Bucher and Frey (1994).

observed as preliminary results in quartz-tourmaline veins (Rimondi et al., 2015a, 2015b).

Microthermometry was performed at Linkam THMSG600 heating-freezing stage coupled with ZEISS POL-BK at CNR-IGG at Florence. The stage was calibrated by using pure $\mathrm{H}_{2} \mathrm{O}$ with critical density, and mixed $\mathrm{H}_{2} \mathrm{O}-\mathrm{CO}_{2}\left(\mathrm{CO}_{2} 25 \% \mathrm{M}\right)$ synthetic fluid inclusions. Accuracy was estimated to be $\pm 0.1{ }^{\circ} \mathrm{C}$ for final ice melting $\left(\mathrm{Tm}_{\text {ice }}\right)$, final hydrohalite melting $\left(\mathrm{Tm}_{\mathrm{hh}}\right)$, and $\pm 1{ }^{\circ} \mathrm{C}$ for the vapour/liquid homogenization (Th) and halite melting temperature $\left(\mathrm{Tm}_{\mathrm{h}}\right)$.

Microthermometric data for $\mathrm{L}$ and $\mathrm{S}$ inclusions are reported in Table 1. Data of both $\mathrm{L}$ and $\mathrm{S}$ inclusions in tourmaline and $\mathrm{S}$ inclusions in quartz of the 3rd faults generation are within the ranges reported in a preliminary study for quartz at Cala Stagnone (Rimondi et al., 2015a, 2015b). For S inclusions, Th (referring to the disappearance of the vapour bubble) covered ranges of $253-328$ and $256-284{ }^{\circ} \mathrm{C}$ for tourmaline and quartz, respectively (Table 1 ); in tourmaline, $\mathrm{Tm}_{\mathrm{h}}$ may occur before or after vapour disappearance with a maximum at $313{ }^{\circ} \mathrm{C}$ (Table 1). In quartz of the $3 \mathrm{rd}$ faults generation, halite dissolved always after vapour disappearance at a maximum of $389{ }^{\circ} \mathrm{C}$ (Table 1 ).

In tourmaline, Th of $\mathrm{L}$ inclusions range from 322 to $540{ }^{\circ} \mathrm{C}$, while $\mathrm{Th}$ values of $\mathrm{L}$ inclusions in quartz of the 3rd generation faults are comprised between 242 and $442{ }^{\circ} \mathrm{C}$ (Table 1 ).

For $\mathrm{L}$ inclusions in tourmaline, $\mathrm{Tm}_{\text {ice }}$ ranged from -24.6 to $-16.1{ }^{\circ} \mathrm{C}$ (Table 1 ), while an eutectic temperature $\left(\mathrm{T}_{\mathrm{E}}\right)$ of $\sim-50{ }^{\circ} \mathrm{C}$ was observed. Comparable $\mathrm{T}_{\mathrm{E}}$ and $\mathrm{Tm}_{\text {ice }}$ were observed for fluid inclusions in quartz of the 3rd faults generation, although $\mathrm{Tm}_{\text {ice }}$ extends to higher values (Table 1). Relatively low $\mathrm{T}_{\mathrm{E}}$ and $\mathrm{Tm}_{\text {ice }}$ lower than $-21.2{ }^{\circ} \mathrm{C}$ in $\mathrm{L}$ inclusions (the eutectic $\mathrm{T}$ for the biphasic $\mathrm{H}_{2} \mathrm{O}-\mathrm{NaCl}$ sys- 

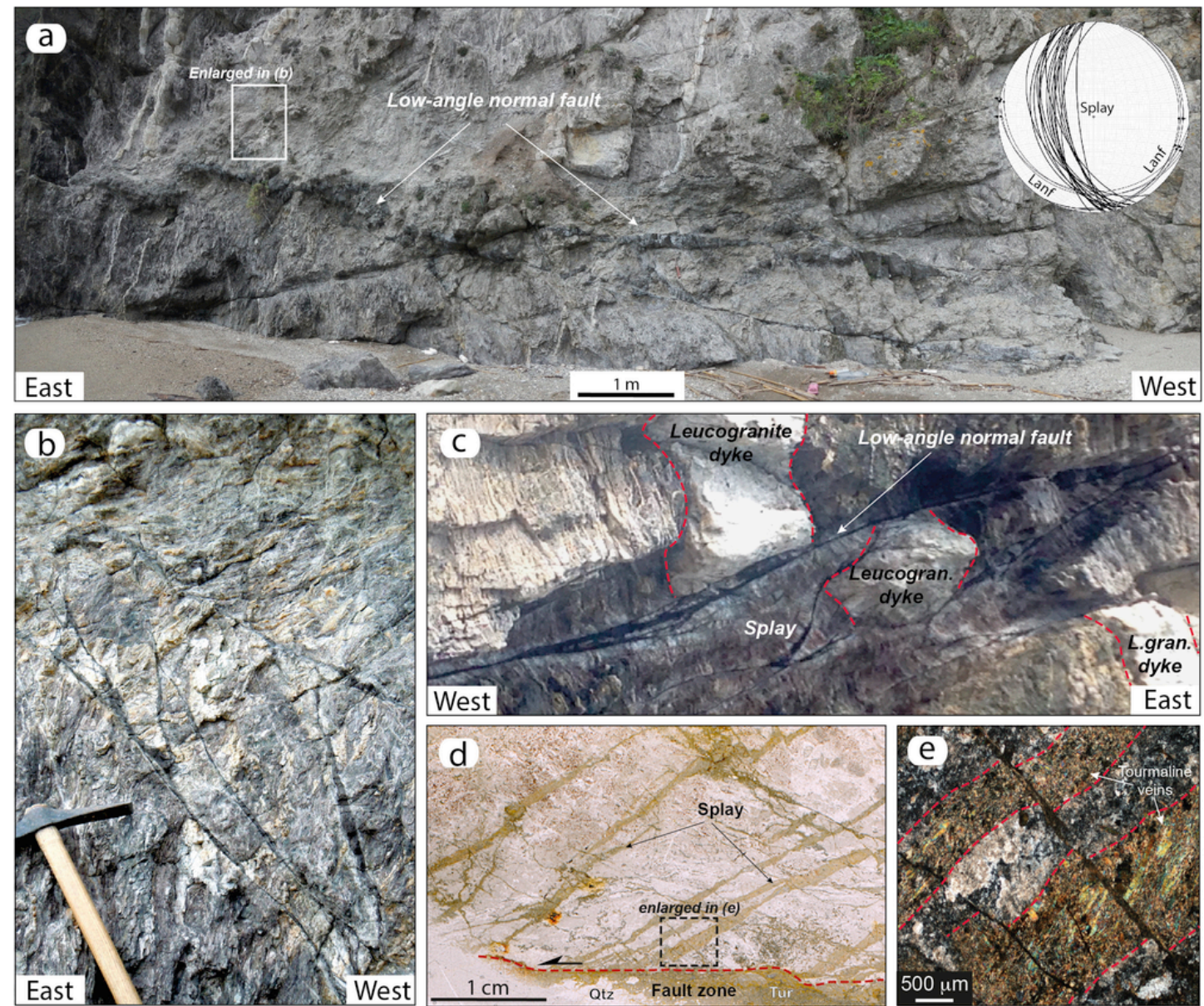

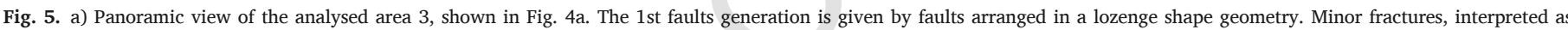

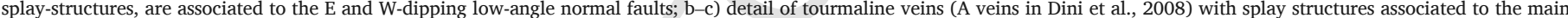
low-angle normal faults. d-e) plane polarized light and crossed polars micrographs showing the syn-tectonic crystalline fabric of the tourmaline veins.

tem) indicated that other divalent cations $\left(\mathrm{Ca}^{2+}, \mathrm{Mg}^{2+}, \mathrm{Fe}^{2+}\right.$ etc. $)$ in addition to $\mathrm{Na}^{+}$are present in many of the examined inclusions (Shepherd et al., 1985).

Salinity for fluid inclusions is conventionally reported as wt.\% $\mathrm{NaCl}$ equivalents (Roedder, 1984; Shepherd et al., 1985) and can be calculated from $\mathrm{Tm}_{\mathrm{ice}}$ following the equation of Bodnar and Vytik (1994), that was extrapolated to temperature lower than $\mathrm{T}_{\mathrm{E}}$ for inclusions displaying $\mathrm{Tm}_{\text {ice }} \geq \mathrm{T}_{\mathrm{E}}$ of the $\mathrm{H}_{2} \mathrm{O}-\mathrm{NaCl}$ system. These salinities were comprised between $19.2-25.5$ wt. and $10.726 .6 \mathrm{wt}$ \% $\mathrm{NaCl}$ eq. for $\mathrm{L}$ inclusions in tourmaline and quartz, respectively.

Salinity for S inclusions, similarly expressed in wt.\% $\mathrm{NaCl}$ eq., was calculated following the methods of Lecumberri-Sanchez et al. (2012) and Steele-MacInnis et al. (2012) for inclusions homogenizing by halite or vapour disappearance, respectively. The $\mathrm{S}$ inclusions salinity in tourmaline (32.3-37.3 wt.\% $\mathrm{NaCl}$ eq.) was comprised in the range measured for the quartz of the 3rd faults generation (38.2-46.7 wt.\% $\mathrm{NaCl}$ eq.) (Table 1).

The all possible trapping conditions of fluid inclusion in tourmaline and quartz are shown in Fig. 9a and b. Minimum temperature and pressure of trapping correspond to homogenization conditions. Isochores were computed for the estimate of maximum trapping temperature and pressure in $\mathrm{L}$ and $\mathrm{S}$ inclusions in tourmaline and in quartz, following the HokieFlincs Microsoft excel spreadsheet (Steele-MacInnis et al., 2012 and reference therein) and Lecumberri-Sanchez et al. (2012). Thus, maximum pressure-temperature conditions (Fig. 9a and b) are constrained by the intersection of isochores with the maximum pressure $(<2 \mathrm{Kbar})$ or the maximum temperature $\left(<650{ }^{\circ} \mathrm{C}\right)$ estimated for the thermometamorphic peak (Duranti et al., 1992). Furthermore, the stability field of andalusite provides a further (mineralogical) constrain to the related isochores.

The occurrence of at least two fluid inclusions populations within both tourmaline and quartz ( $\mathrm{L}$ and S), the relatively large ranges of their microthermometric data (particularly Th) and the variable compositions of veins tourmaline pointed out to fluids with a composite physical-chemical evolution (Dini et al., 2008; Rimondi et al., 2015b; Zucchi et al., 2016). Although this variability, the occurrence of both L and S inclusions in tourmaline of 1st faults generation and in quartz of 3rd faults generation suggests that all the faults generations experienced the circulation of similar fluid(s).

\subsection{Key-areas, scan lines and scan boxes}

On the basis of this survey, three key-areas were mapped at 1:100 scale (Fig. 4a). Here, the reconstruction of the mineralized fault-slip zones array was essential to plan the location and geometrical configuration of the scan-lines and scan boxes. By this approach, the geometrical parameters (mineralized slip zone width and length) necessary for the permeability estimation were collected. In all study areas, the mineralized slip zones were sampled in order to relate the geochemical features of the circulating paleo-fluids to the different faults generations.

Area 1 (map-view, Fig. 10) shows that the 1st faults generation is widely exposed favouring collection of kinematic indicators and samples for fluid inclusion analysis. Structures belonging to the 2nd faults generation are defined by high-angle NNW-trending faults. No clear 

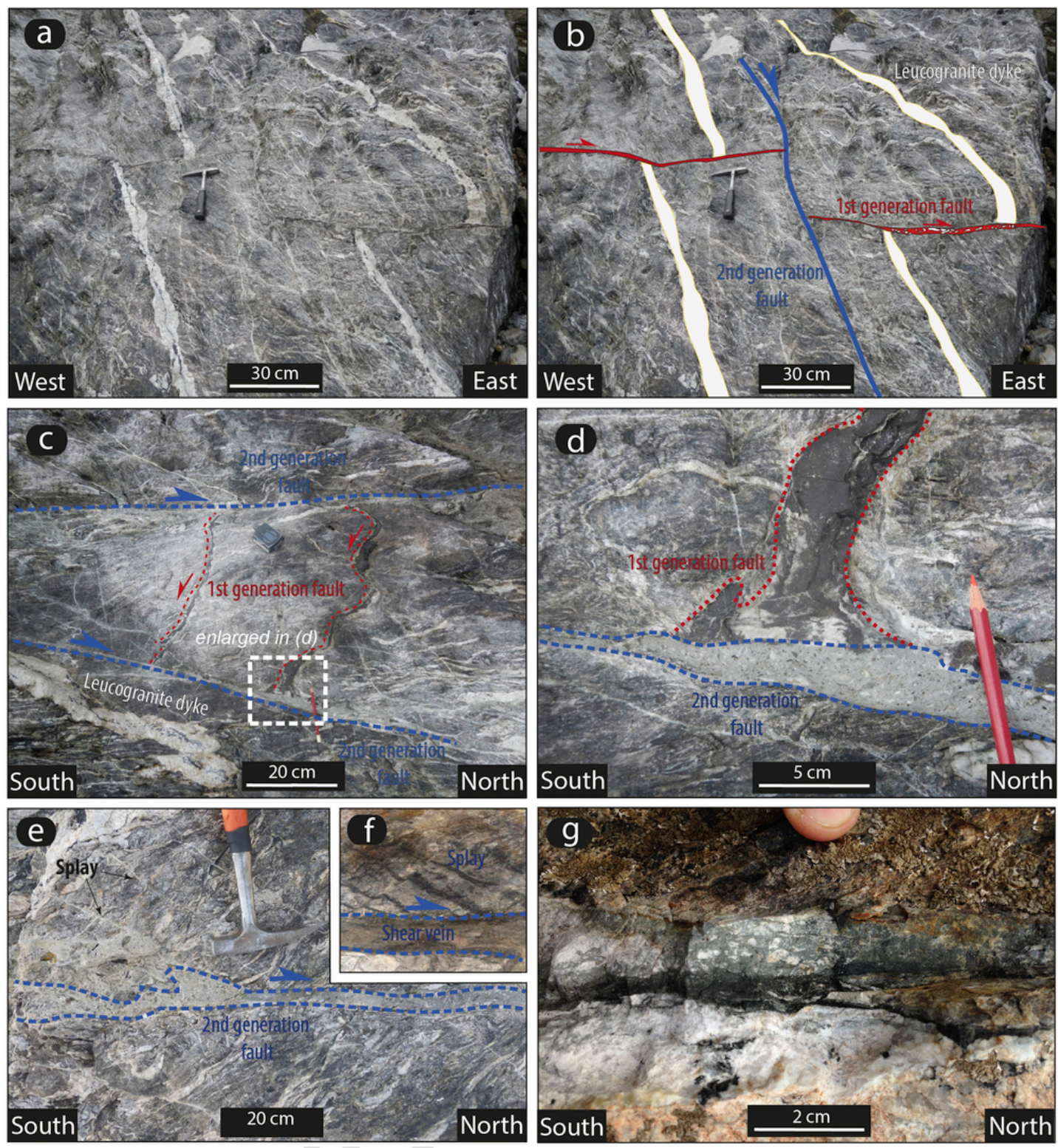

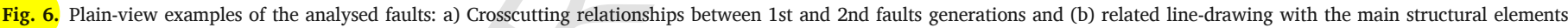

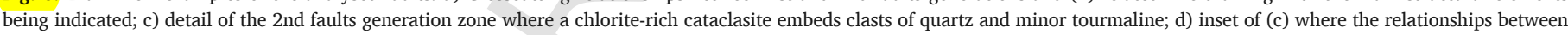
the cataclasite along the main slip zone and the splay-structures can be recognised; e-f) detail of minor splay-structures associated to the main 2nd faults generation.

kinematic indicators have been recognised on their slip surfaces; however, a component of right-lateral movement is clearly indicated by their offsets (Fig. 10). The 3rd faults generation is only represented by minor structures, consisting of tiny quartz veins, not reported on this map. However, their structural data have been collected and summarized in the stereographic diagrams.

Area 2 (Fig. 10), similarly to Area 1, shows the already described relationships among dykes, 1st and 2nd faults generations (Fig. 6). The 3rd faults generation is also mapped, resulting in localised brittle shear zones, with a main dextral component (Fig. 7b).

Area 3 (Fig. 10) is represented by the vertical exposure illustrated in Fig. 5a, where the 1st faults generation forms a lozenge-shaped geometry, with planes both dipping to the East and to the West. Their cross-cutting relationships suggest a coeval development. These low-angle faults are connected through $40-50^{\circ}$ west-dipping splay tourmaline-rich (B-veins, in Dini et al., 2008) fractures (Fig. 5b-f). The 2nd faults generation is represented by steep-dipping faults (Fig. $5 \mathrm{~g}$ ), whereas the 3 rd faults generation, given its almost vertical attitude and tures, is not distinguishable from the vertical quartz layers defining the micaschist metamorphic fabric, at least at the outcrop scale.

Scan-lines (3-12 $\mathrm{m}$ in length) have been measured in the three selected areas (Fig. 10) to quantify the minimum (m) and maximum (M) spacing of the mineralized faults (Fig. 11), assuming the scan-line length as the maximum possible spacing value between two similar mineralized veins.

Their orientation is almost normal to the trend of the 1st and 2nd faults generations and is at high angle with respect to the 3rd faults generation. The spacing between scan-lines was defined in $2 \mathrm{~m}$, considering the outcrop conditions and the width of the study key-areas.

In all scan-lines (Fig. 11) the 1st and 2nd faults generations are generally displayed, although their coexistence in the same scan-line is not a common feature. The 3rd faults generation is present in F-G-H scan-lines, only. Vertical I-J-K scan-lines illustrate the 1st faults generation.

The minimum spacing value (i.e. $0.2 \mathrm{~m}$ ) between two forthcoming similar fault-slip zones has been taken in account to define the size of the scan-box, thus fixed in $0.4 \mathrm{~m}$ per side (Fig. 12). The minimum 

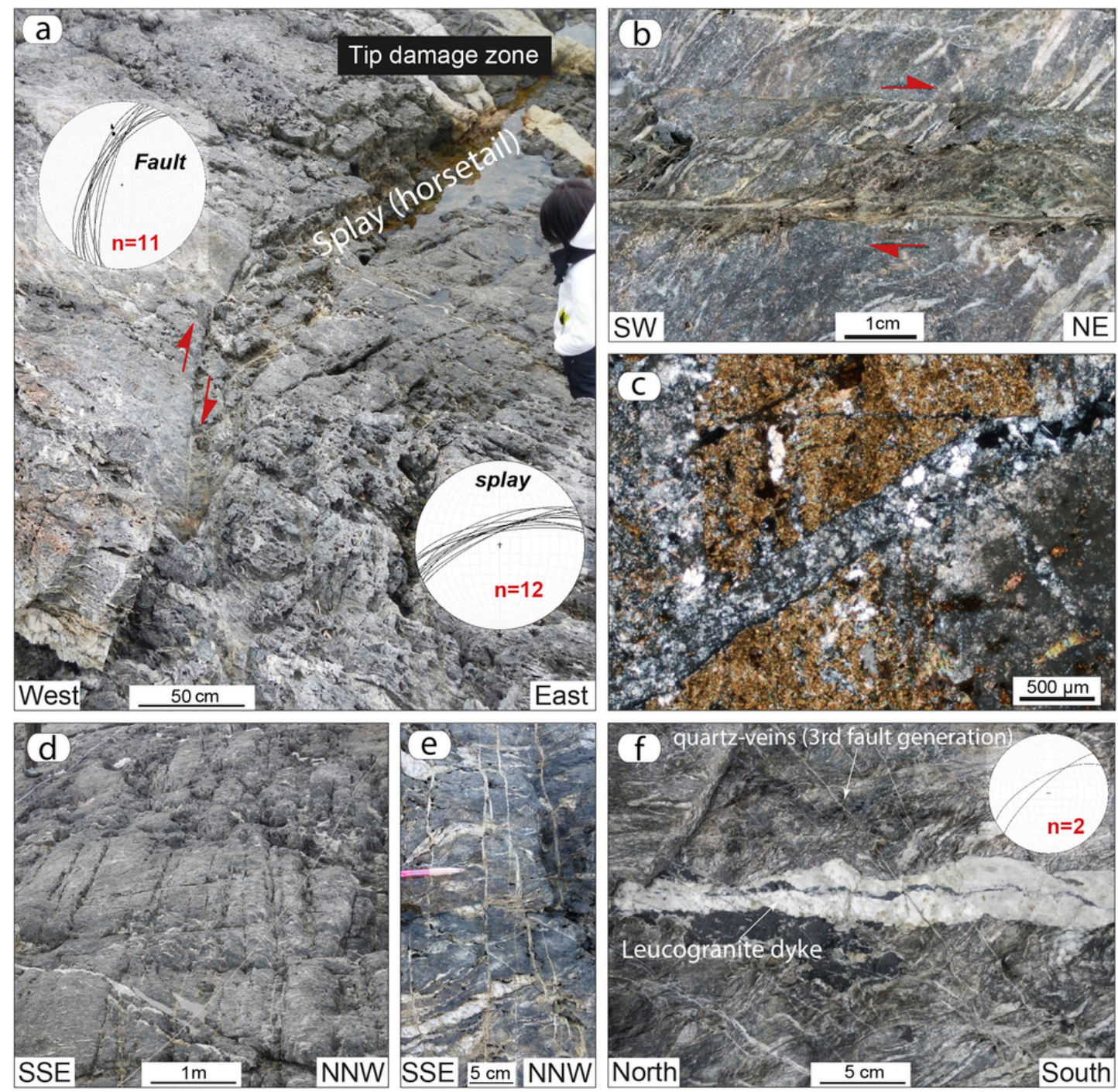

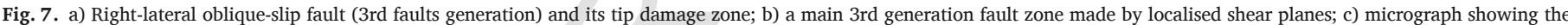

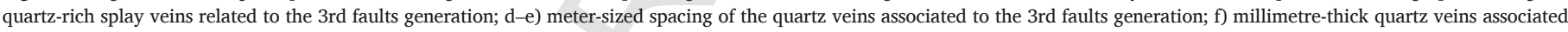
to the 3rd faults generation.

amount of the maximum fault spacing value (i.e. $1.3 \mathrm{~m}$ ) has been differently considered to define the scan-box spacing (i.e. $1 \mathrm{~m}$ ), along the scan line.

Within each scan-box, collection of data (i.e. mineralized fault length, minimum and maximum mineralized slip-zone width, and number of structures for each fault generation) has been carried out in the field, when the size of structures was suitable for the direct measurement. Differently, image analyses were performed (by the free software Image J 1.45) for pictures taken at right angle to the scan-box surface. By this methodology, structures from $30 \mathrm{~cm}$ to less than a millimetre in size were considered.

The analysed fracture dataset consists of about 450 data. Fig. 13 summarizes the collected data, as measured within each scan-box of each scan-line for the different faults generations. The diagrams show: a) the number of structures; b) the sum of the length of all structures belonging to the same generation; $\mathrm{c}$ ) averaged minimum and maximum thickness of the mineralized slip zones, belonging to the same fault generation.

The splay structures belonging to the 3rd faults generation are present in almost all scan-boxes, with numerosity ranging from 1 (Fig. 13a) to 23 (Fig. 13i) for each scan-box. Differently, the mineralized fault-slip zones of the 2nd faults generation are missing in several scan-boxes (Fig. 13e, i, m and y) although, when present, their numerosity reaches a maximum of 14 (Fig. 13s). The 1st faults generation is present in all diagrams, ranging between 1 (Fig. 13a and i) and 13 (Fig. 13a).

The sum of the length of all structures belonging to the same generation was computed for each scan-box. This analysis highlights that a high numerosity does not always imply a high value of total length. The best example of this is provided by the comparison of Fig. $13 \mathrm{~m}$ with Fig. 13n, where scan-boxes between 0 and $1 \mathrm{~m}$ and $6-7 \mathrm{~m}$, although showing the same number of 1st and 3rd faults generation (Fig. 13m), display a different total length for the considered generation (Fig. 13n). On the contrary, number of structures within the $0-1 \mathrm{~m}$ scan-box of the scan-line G (Fig. 13v) indicates a large difference between the 2nd and the 3rd faults generations ( 1 and 9, respectively) but a similar total length (Fig. 13w).

Values of the averaged minimum and maximum widths are significantly different only for the 1st faults generation, varying between few centimeters (e.g. Figs. 13c, g and o) to some decimeters (e.g. Fig. 14c and i). Differently, the averaged minimum and maximum widths of the 2nd faults generation are encompassed between few millimeters to 


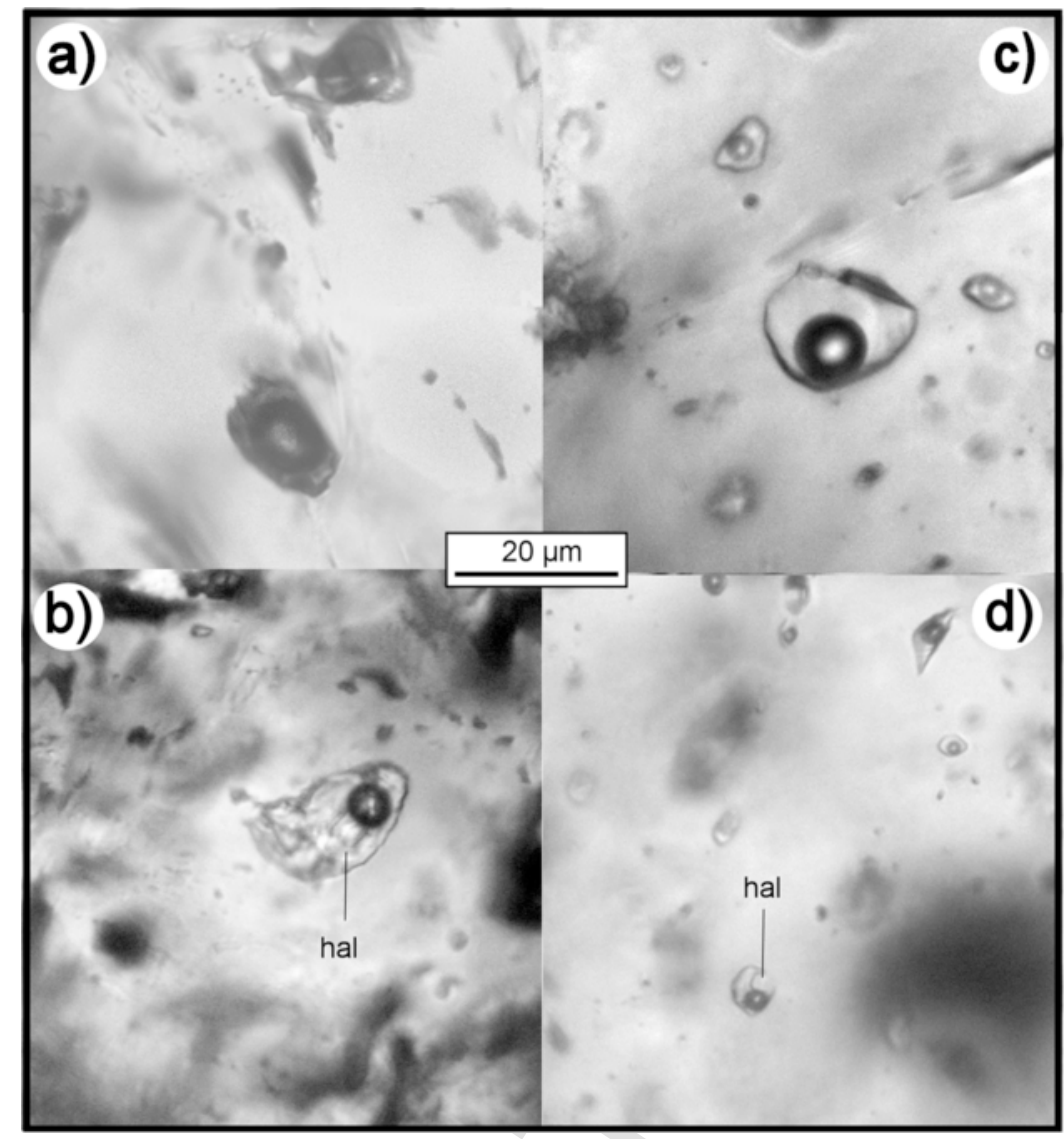

Fig. 8. a,b) Micrographs in transmitted light of fluid inclusions in a,b) tourmaline of the 1st faults generation; c,d) quartz of the 3rd faults generation; hal = halite.

Table 1

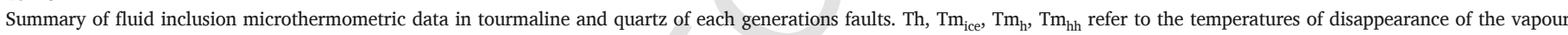
bubble, melting of ice, halite and hydrohalite respectively.

\begin{tabular}{|c|c|c|c|c|c|c|c|}
\hline Generation faults & Mineral & FI type & $\operatorname{Tm}_{\text {ice }}\left({ }^{\circ} \mathrm{C}\right)$ & Th $\left(^{\circ} \mathrm{d}\right.$ & $\operatorname{Tm}_{\mathrm{h}}\left({ }^{\circ} \mathrm{C}\right)$ & $\mathrm{Tm}_{\mathrm{hh}}$ & Salinity ( $\mathrm{NaCl}$ wt.\% eq.) \\
\hline \multirow[t]{2}{*}{$1 \mathrm{st}$} & tourmaline & $\mathrm{L}$ & $-24.6 /-16.1[11]$ & $322 / 540[8]$ & / & $-26[2]$ & $19.2 / 25.5$ \\
\hline & & $S$ & n.d. & $253 / 328[8]$ & $213 / 313[6]$ & / & $32.3 / 37.3$ \\
\hline \multirow[t]{2}{*}{ 3rd } & quartz & $\mathrm{L}$ & $-26.3 /-7.1[70]$ & $242 / 442[94]$ & / & $-26 /-1.2[19]$ & $10.7 / 26.6$ \\
\hline & & $\mathrm{S}$ & n.d. & $256 / 284[5]$ & $297 / 389[5]$ & / & $38.2 / 46.7$ \\
\hline
\end{tabular}

about 2 centimeters (e.g. Fig. 13r, 13x), whereas the values related to the 3rd faults generation range between 0.1 and $4 \mathrm{~mm}$.

In summary, the 3rd faults generation, the most diffuse, is the one showing the lowest averaged width value. On the contrary, the 1st faults generation displays the higher values of averaged width and total length.

\subsection{Permeability estimation}

Permeability can be mathematically estimated using the parallel plate model, assuming a laminar fluid flow and combining continuous fractures with different orientations, apertures, and spacing (Gale, 1982). It implies that fractures with permeability greater than $10^{-12} \mathrm{~m}^{2}$ cannot be approximated by this model (Gale, 1982; Nicholl et al., 1999).

The parallel plate model was used in many studies. Among them, it is worth mentioning Zimmerman and Bodarsson (1996) and Leung and Zimmermann (2012) who used it as a basis to evaluate the hydraulic conductivity of rock fractures and two-dimensional fracture networks.

Estimation of permeability has been obtained through the following Eq. (1), modified after Gale (1982) for the permeability of a medium containing a single fracture, characterized by a width lower than $2 \mathrm{~mm}$ :

$k=\left(\frac{2}{3} \times \frac{b^{3}}{L}\right)$

where $b$ is the average fracture width and $L$ is the fracture length.

Gale (1982) evaluated the permeability of the medium, by summing the contributions of each individual fracture, at a given sampling station. Some authors (e.g. Cox, 2001; Nicholl et al., 1999) discussed the approximation of the parallel plate model. Nicholl et al. (1999) demonstrated that, approximating the fracture roughness and internal connectivity to a series of rock-wedges, if wedges have a connecting angle lower than $30^{\circ}$, the relative transmissivity is reduced at most by a factor of 0.7 ; differently, for a connecting angle of $60^{\circ}$, the reduction is by a factor of 0.4 .

Many authors have debated on the connectivity of the fracture network. According to Leung and Zimmermann (2012), the fact that the effective conductivity of the fracture segments can be approximated by the arithmetic mean is explained as follows: if fracture aperture is positively correlated with length, then the fracture network will be domi- 

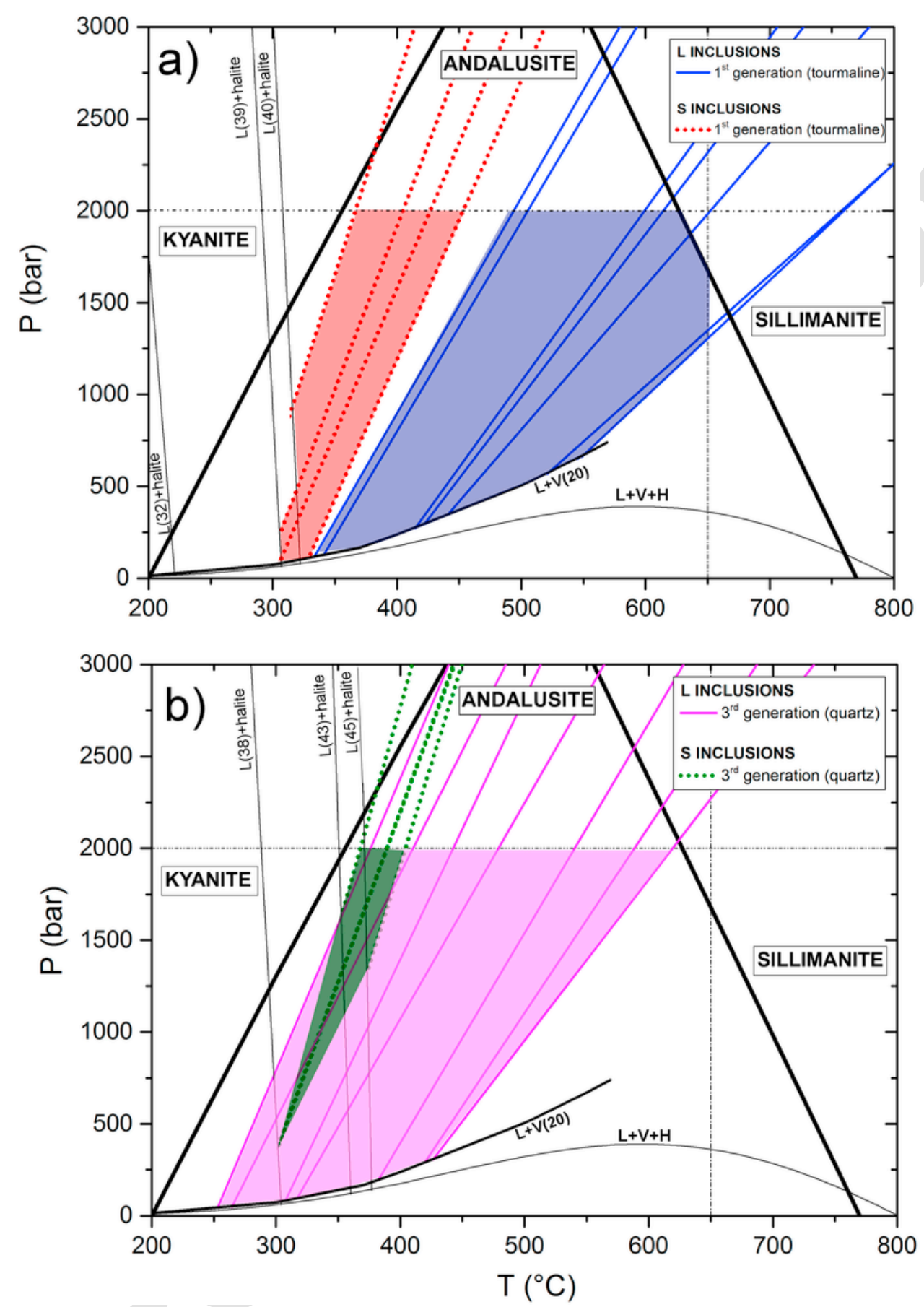

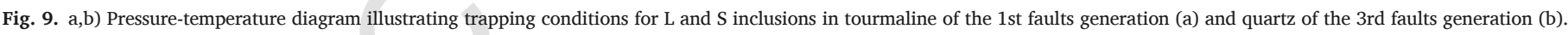

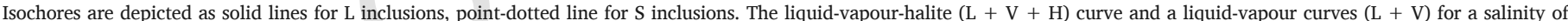

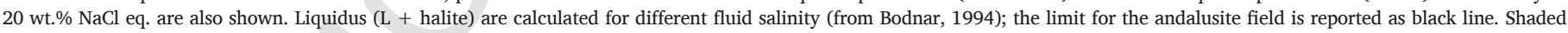
area defines the P-T trapping conditions for $\mathrm{L}$ and $\mathrm{S}$ inclusions.

nated by a relatively small number of long fractures, with high conductivity. These long fractures will act more efficiently if their array can be described as "parallel" fractures, thus each of these fractures can transmit fluid across large distances, without the need that fluids pass through the less efficient fractures of the network.

The effective conductance of a set of conductors arranged in parallel array is governed by the arithmetic mean rather than the geometric or harmonic mean. The geometric mean is a special case of power law averaging, extensively used by de Dreuzy et al. (2001a, 2001b, 2002). In our case, being the system dominated by very long fractures ( 1 st and 2nd faults generation, at least), we assume that the geometric mean of the permeability is the best approximation, although the arithmetic mean was considered for comparison.

According to these considerations, we modified the Eq. (1) as follow:

$k=\left(\frac{2}{3} \times \frac{b^{3}}{L}\right) \times F \cdot 10^{-6}$

where $\mathrm{F}$ is the connectivity parameter ranging from 0 to 1 . On the basis of the main geometrical configuration of the analysed structures 


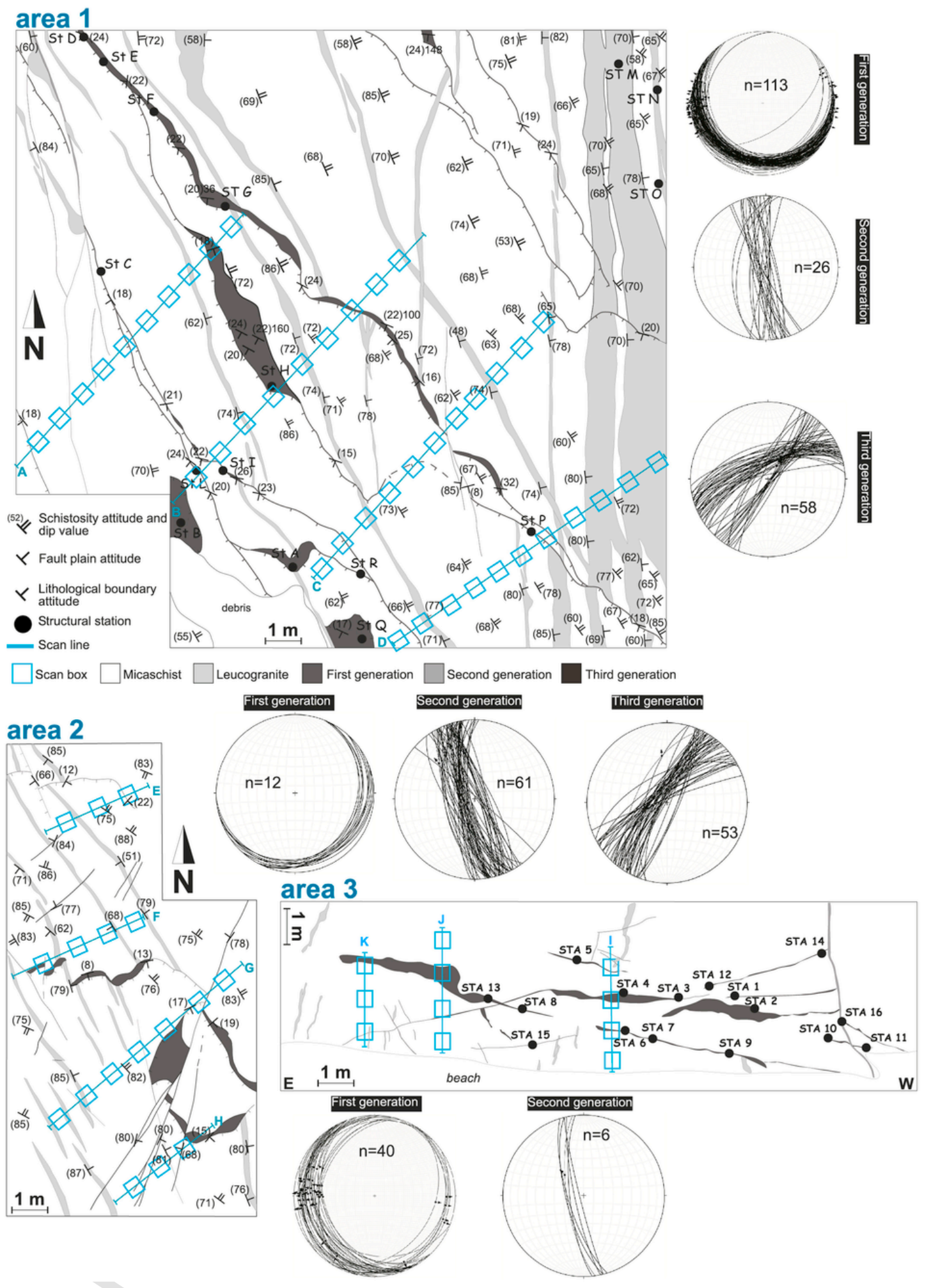

Fig. 10. Detailed structural map of the indicated areas reported in Fig. 4a. Analysed scan-lines and scan-boxes are also reported for the whole areas.

(angles of about $60^{\circ}$ ), we have considered $\mathrm{F}=0.4$. However, even considering $\mathrm{F}=0.7$ the results do not change significantly, revealing the scarce influence of the used $\mathrm{F}$ value on the permeability estimation.

The $\mathrm{b}$ and $\mathrm{L}$ parameters derive from the fieldwork structural data collection, described in the previous section. When fractures are wide more than $2 \mathrm{~mm}$, thus beyond the limiting width value for the plate model theory, these are interpreted as the result of repeated deforma- tional events and their deriving permeability values were considered reasonable only for $\mathrm{k}<10^{-12} \mathrm{~m}^{2}$.

The $\mathrm{b}$ and $\mathrm{L}$ parameters were obtained for each generation of mineralized structures, within each scan-box (Fig. 10) of each scan line. Then, by Eq. (2), the permeability of each mineralized structure was computed. Finally, a permeability value for each faults generation was defined through the harmonic average (Table 2). 


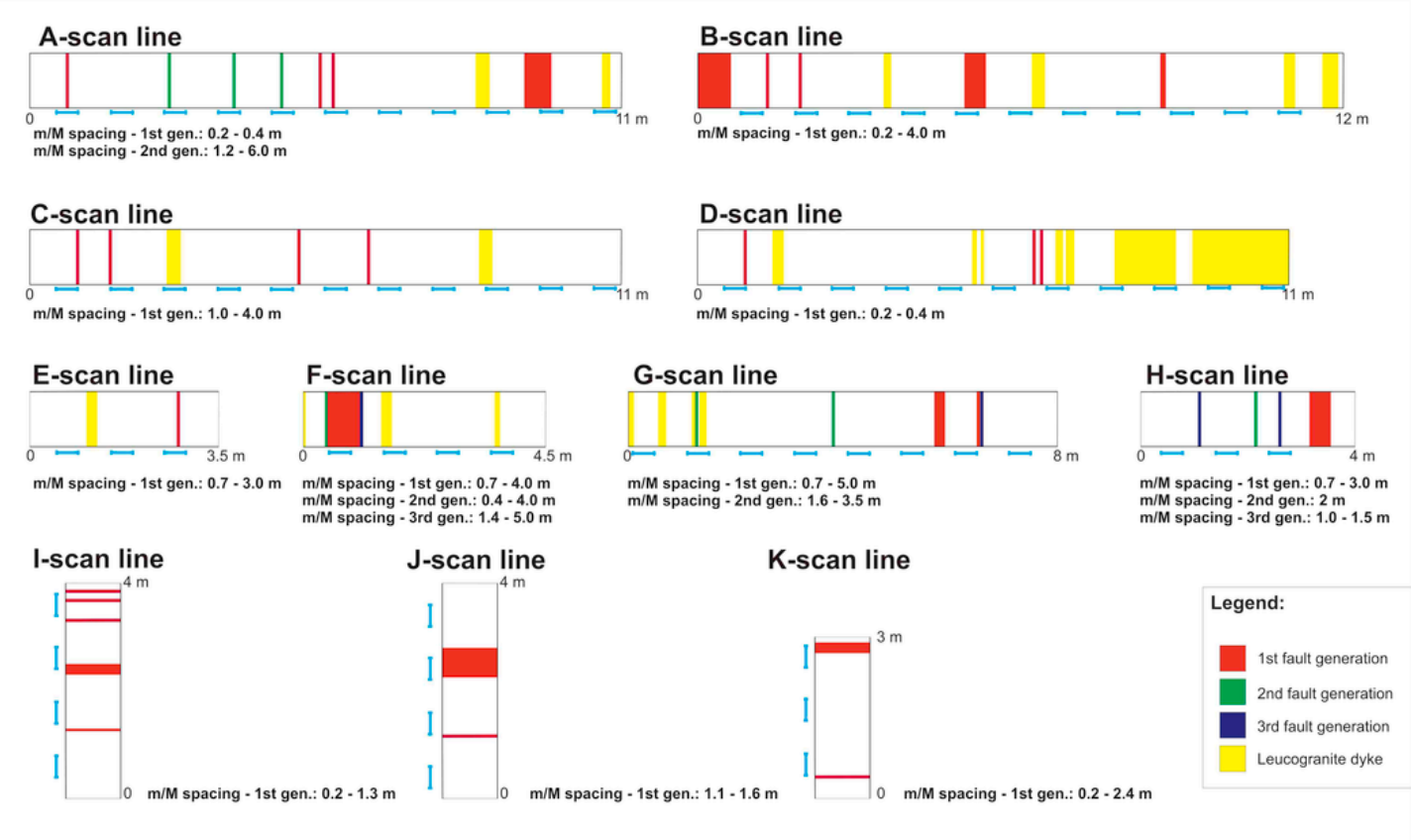

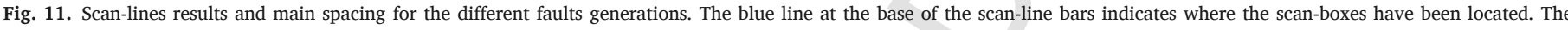

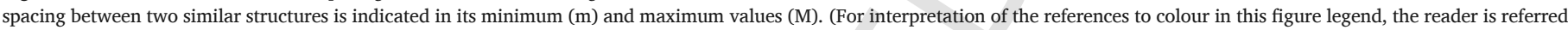
to the web version of this article.)
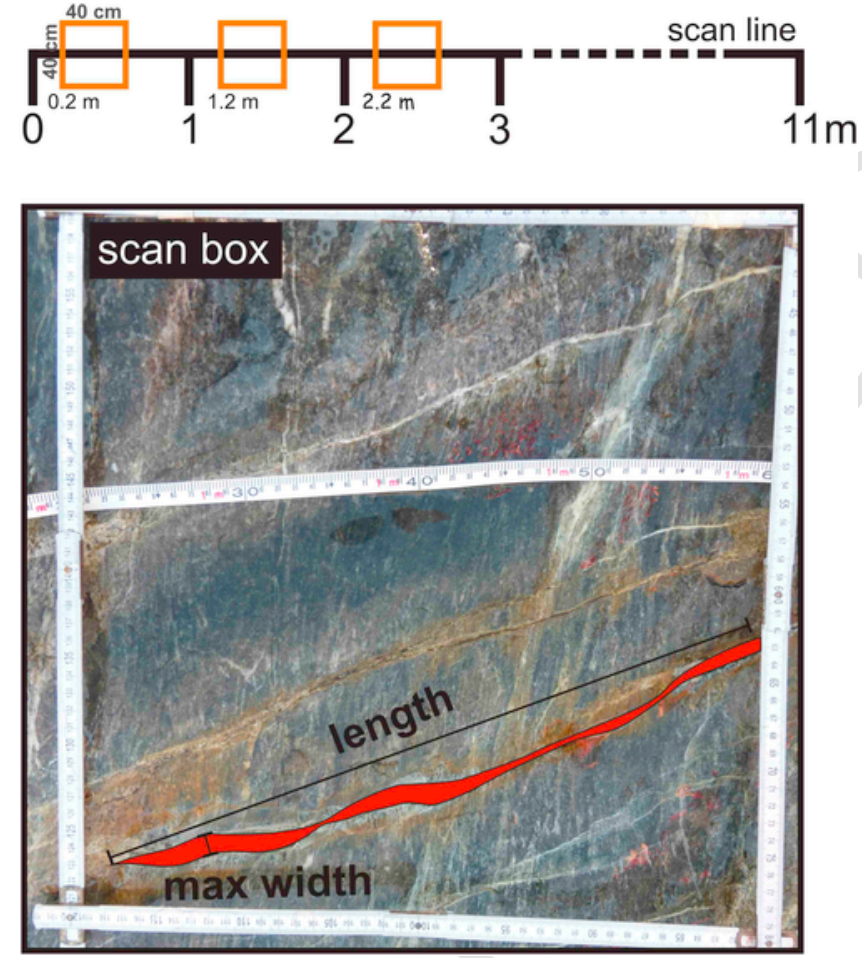

Fig. 12. Example of the geometric parameters collected within each scan-box, along each scan line, for the k estimation.

Fig. 15 summarizes the results about permeability and efficient porosity, respectively, computed for each scan box, along each scan line. Efficient porosity derives from the ratio between mineralized fractures and scan box areas.

Generally, the higher permeability values are from the 1st faults generation, with values up to $10^{-12} \mathrm{~m}^{2}$ whilst the lower ones are from the 3rd faults generation. Both these generations are shown in all dia- grams. Differently, the structures of the 2nd faults generation are only occasionally present. The efficient porosity (Fig. 15) displays a distribution similar to that of the permeability.

Finally, the whole $\mathrm{k}$ values have also been analysed through frequency distribution diagrams (Fig. 16) in order to define the characteristic value for each fault generation. In a more detail, the $\mathrm{k}$ frequency distribution for the 1st faults generation (Fig. 16a) displays three peaks, suggesting three main populations (Fig. 16b, c and d), with $10^{-14}<\mathrm{k}<10^{-16} \mathrm{~m}^{2}$ as the main representative values. A smaller interval is instead characterising the 2nd faults generation (Fig. 16d) where significant values of $\mathrm{k}$ are comprised between $10^{-14}$ and $10^{-13} \mathrm{~m}^{2}$. Finally, the 3rd faults generation distribution of data is characterized by two main peaks, from which the most significant permeability results comprised between $10^{-15}$ and $10^{-17} \mathrm{~m}^{2}$ (Fig. 16e).

\subsection{Viscosity and hydraulic conductivity estimations}

Based on the fluid inclusions results previously described (i.e., salinity, maximum and minimum pressure-temperature conditions for both $\mathrm{L}$ and $\mathrm{S}$ inclusions), maximum and minimum fluid density and viscosity were computed through the software SoWat $\mathrm{NaCl}-\mathrm{H}_{2} \mathrm{O}$ (Driesner, 2007; Driesner and Heinrich, 2007), following the water-NaCl Equation of State (EOS, available online at http://baobab.istep.upmc.fr/model. php) as proposed by Dubacq et al. (2013), using the method described in Mao and Duan (2009).

Fluid viscosity was computed for the two kinds of fluid inclusions (L and S) and for all the faults generations at the minimum pressure conditions (i.e at homogenization conditions), and at maximum pressure trapping conditions (Fig. 9a and b). For the 2nd faults generation, we employed the density data obtained from the fluid inclusion in tourmaline of the 1st faults generation. L inclusions type for 1st and 2nd faults generation results in a density of $661-889 \mathrm{~kg} / \mathrm{m}^{3}$ and in viscosity ranges of 3.29/5.91 E + 01 and 7.06 E + 01/1.24 E + $02 \mu \mathrm{Pa*s}$ for low- and high-pressure, respectively (Table 3). Density values for fluid inclusions in quartz of the 3rd faults generation are in the range of $777-1029 \mathrm{~kg} / \mathrm{m}^{3}$, while viscosity is comprised between $2.72 / 4.81$ 

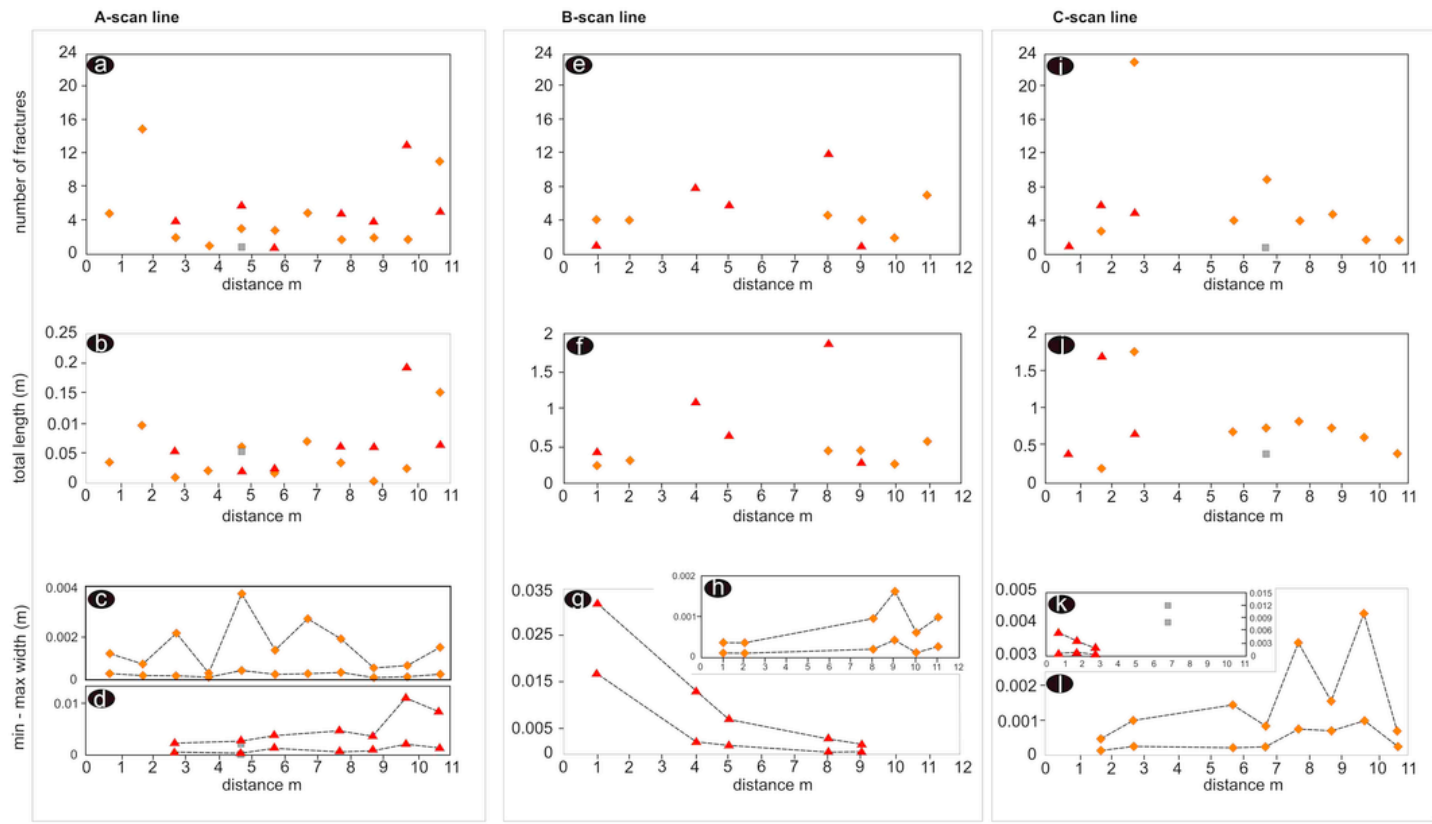

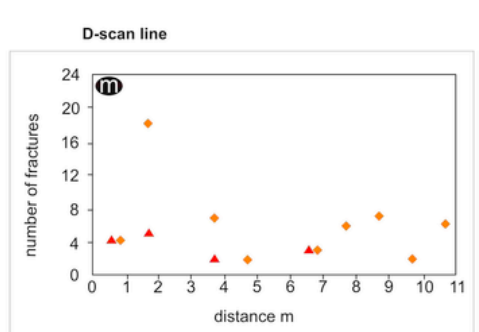

\section{E-scan line}

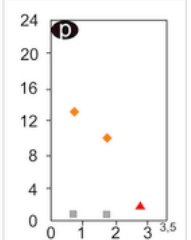

distance $m$
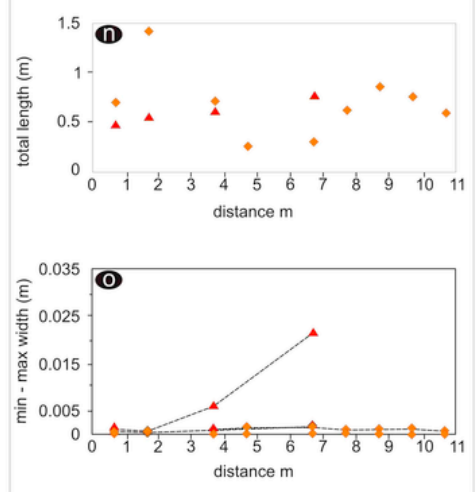

A $1^{\text {st }}$ faults generation
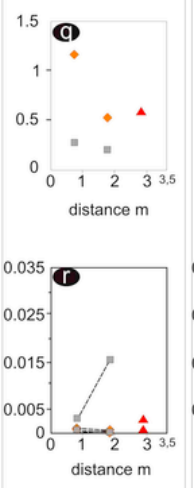

(1)
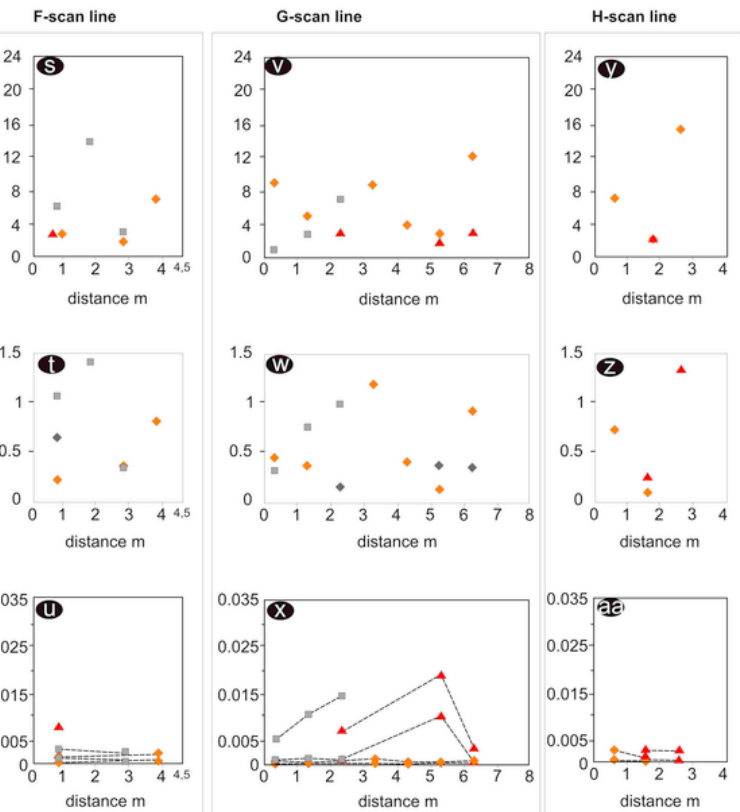

$2^{\text {nd }}$ faults generation

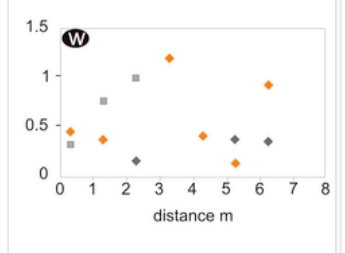

distance $m$

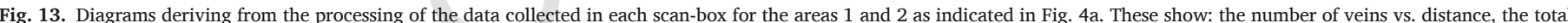

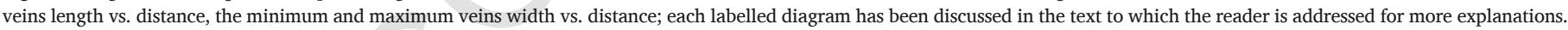

$\mathrm{E}+01$ and $9.56 \mathrm{E}+01 / 1.61 \mathrm{E}+02 \mu \mathrm{Pa}$ *s for low and high pressure, respectively (Table 3$)$. At low pressure, $S$ inclusions generally display comparable viscosities to L inclusions (Table 3); whereas at high pressure, $\mathrm{S}$ inclusions displayed always higher viscosity, with values generally higher than $200 \mu \mathrm{Pa}$ *s (Table 3 ).

Considering permeability in addition to the parameters listed in Table 3, the hydraulic conductivity ( $\mathrm{K}$, measured in $\mathrm{m} / \mathrm{s}$ ) can be estimated by the Eq. (3), at low and high-pressure conditions:

$K=\frac{\rho \times k}{\eta}$

where $\mathrm{k}$ is permeability, $\rho$ is density and $\eta$ is viscosity. The computation was carried out for the minimum and maximum permeability values for each generation of faults and for the $\mathrm{L}$ and $\mathrm{S}$ inclusions (Table $3)$.

\section{Discussion}

This section will be focused on two main points: a) relationships between structures and tourmaline mineralization; b) estimation of permeability and hydraulic conductivity.

\subsection{Structures and tourmaline mineralization}

Tourmaline is the most significant mineralogical phase associated to the first hydrothermal event during the Porto Azzurro magma cooling 


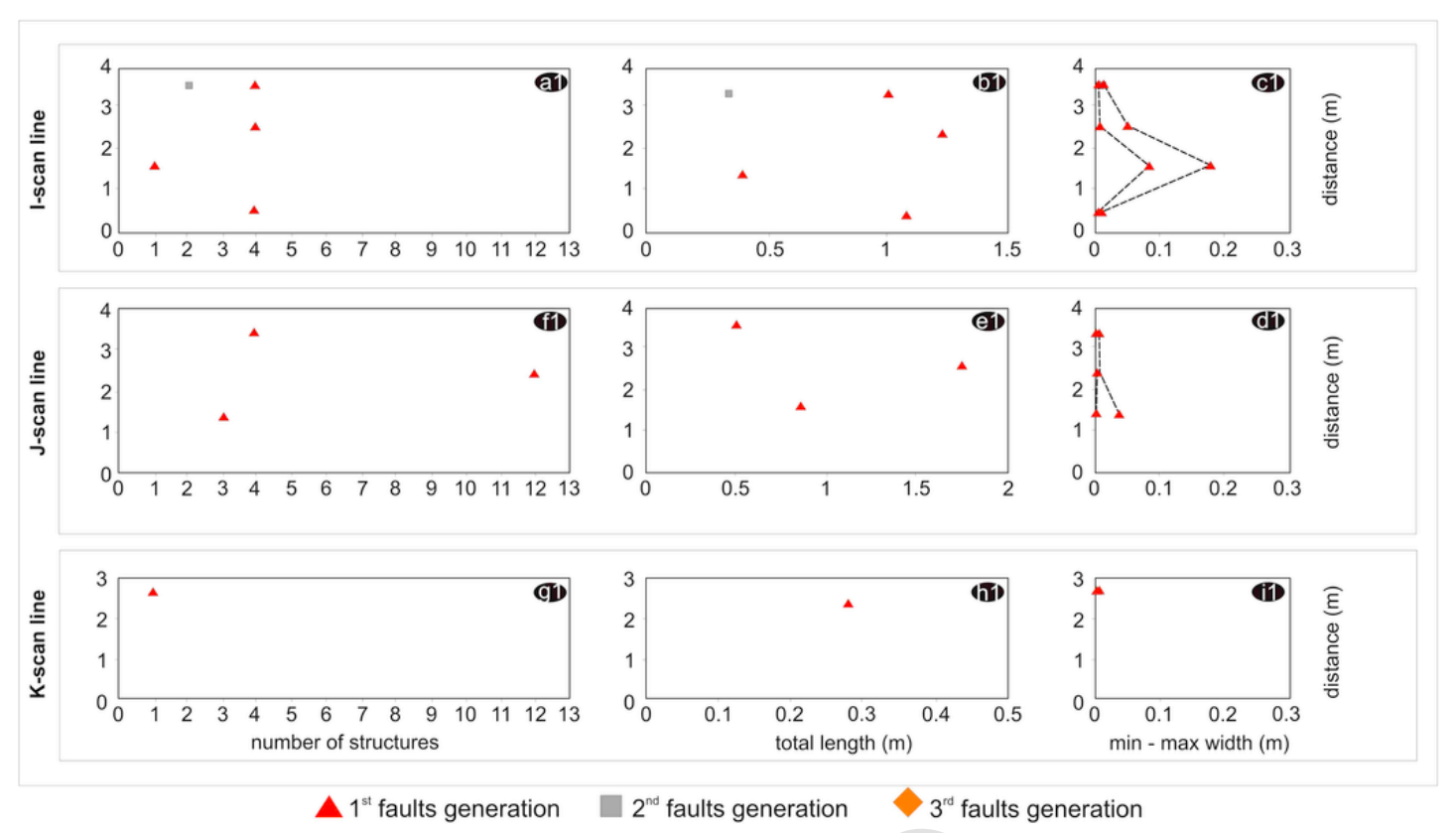

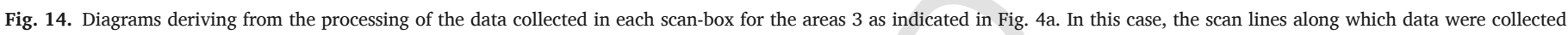
are vertical. Symbols and explanation as in Fig. 13.

(Dini et al., 2008). Such an event can be therefore referred to the timespan encompassed between $6.2 \mathrm{Ma}\left({ }^{40} \mathrm{Ar} /{ }^{39} \mathrm{Ar}\right.$ datings on muscovite, Musumeci et al., 2011), considered as the age of the contact metamorphism, and 5.4 Ma ((U + Th)-He datings on hematite and K/Ar datings on adularia, Lippolt et al., 1995), assumed as the age of the Fe-ore deposits post-dating the tourmaline mineralization (Liotta et al., 2015). Hydrofracturing and fabric of tourmaline veins (Figs. 4 and 5) imply that tourmaline deposition occurred during fault activity. Kinematics on 1 st faults generation clearly indicates a normal to transtensional movements in the W-E direction, depending on the fault segments dipping attitude, thus defining the lozenge shape geometry, associated to this faulting event (Fig. 5). This extensional tectonic framework agrees with the one deriving from the studies at shallower structural depth, and in particular to those dealing with the Zuccale extensional fault (Fig. 2), described by several authors (Keller and Pialli, 1990; Duranti et al., 1992; Pertusati et al., 1993; Collettini and Holdsworth, 2004; Collettini et al., 2006; Smith et al., 2008; Smith et al., 2011; Liotta et al., 2015). The lozenge shaped geometry observed at the Cala Stagnone area is therefore referred to the typical deformational fabrics at deep structural levels, where pressure and temperature favour a quasi-symmetric shearing.

The 2nd faults generation is locally characterized by a mineralogical association with quartz and tourmaline similar to that of the 1st faults generation, suggesting the involvement of B-rich fluids also during this fault activity (Fig. $6 \mathrm{~g}$ ). Although data are few, the kinematics of the 2nd faults generation is consistent with the one of the 1st faults generation. The 3rd faults generation appears to maintain the kinematic characteristics of the 2nd faults generation.

The Stagnone area was also described in Dini et al. (2008) and Mazzarini et al. (2011). Dini et al. (2008) explained the tourmaline veins (A and B veins) as interconnected and developed during the same hydrothermal event, although B-bearing fluids display slight compositional differences. This interpretation is also in agreement with our observations (Fig. 5b-f), referring their A-veins as splay of the low-angle normal faults (B-veins, in Dini et al., 2008) here previously described.

Differently, Mazzarini et al. (2011) explain the A-veins as minor extensional structures located at the outer arc of a regional fold, whose development is controlled by the neutral surface folding mechanism.
Similarly, their B-veins (corresponding to those structures that we have described as 1st faults generation) are interpreted as conjugate structures developed in a shortening context, i.e. in the inner part of the fold, below the neutral surface. In Mazzarini et al. (2011)'s view, a downward migration of the neutral surface (toward the fold core) is also supposed during deformation, determining the overprint of extensional structures on the previous formed structures. Cala Stagnone is indicated as the key-area for this evolution. However, at Cala Stagnone only extensional and trans-tensional structures (active during the hydrothermal stage) were detected, without any indication of conjugate shear structures formed in a previous, dominantly, shortening setting.

Concluding, the structural and kinematic dataset from Cala Stagnone can be better framed in the Neogene extensional (rather than compressional) tectonic evolution of the northern Tyrrhenian Sea (e.g.: Bartole, 1995; Carmignani et al., 1995) and of the whole Northern Apennines inner zone (Carmignani et al., 1994; Liotta et al., 1998; Brogi et al., 2005), where different generations of normal faults produced the progressive thinning of the previously over thickened (Rossetti et al., 2002; Molli, 2008; Brogi, 2008; Brogi and Giorgetti, 2012; Bianco et al., 2015) continental crust and lithosphere, accompanied by emplacement of crust- and mantle-derived magmatic bodies (Peccerillo, 2003; Dini et al., 2005).

\subsection{Permeability and hydraulic conductivity estimation}

The method to estimate permeability 2 d hydraulic conductivity (K) is based on the measurements of the vein length and thickness, as previously described. It is therefore assumed that veins with the same mineralogical association have been contemporaneously active. This is also a consequence of the fact that, given the comminution of mineral-filling veins, indications about the evolution of veins (e.g. Oliver and Bons, 2001; Bons et al., 2012) were not recognizable, thus determining a simplification, although length and width of veins can be the result of multiple deformational events, occurred during faults activity. In this framework, an overestimation of the $\mathrm{k}$ values is possible and cannot be totally avoided. Nevertheless, this limit is counterbalanced by the statistical approach, which tends to highlight the most suitable value, cutting away those results deriving from veins with a thickness in the or- 
Table 2

Example of the database with the collected geometric data in each scan box along each scan line used for the computation of the k parameter.

\begin{tabular}{|c|c|c|c|c|c|c|c|c|c|c|}
\hline $\begin{array}{l}\text { SCAN } \\
\text { LINE }\end{array}$ & $\begin{array}{l}\text { SCAN } \\
\text { BOX }\end{array}$ & $\begin{array}{l}\text { FRACTURE } \\
\text { GENERATION }\end{array}$ & $\begin{array}{l}\text { average } \\
\text { DISTANCE }\end{array}$ & $\begin{array}{l}\text { FRACTURE } \\
\text { NUMBER }\end{array}$ & $\begin{array}{l}\min \text { WIDTH } \\
(\mathrm{m})\end{array}$ & $\begin{array}{l}\max \text { WIDTH } \\
(\mathrm{m})\end{array}$ & $\begin{array}{l}\text { average } \\
\text { WIDTH }\end{array}$ & $\begin{array}{l}\text { LENGTH } \\
(\mathrm{m})\end{array}$ & $\mathrm{K}\left(\mathrm{m}^{2}\right)$ & $\begin{array}{l}\text { HARMONIC } \\
\text { AVERAGE }\end{array}$ \\
\hline \multirow[t]{11}{*}{ A } & 6 & I & 5.7 & 1 & 0.0015 & 0.004 & 0.00275 & 0.192 & $2.89 \mathrm{E}-14$ & $2.89 \mathrm{E}-14$ \\
\hline & & III & 5.7 & 1 & 0.0001 & 0.0002 & 0.00015 & 0.046 & $1.96 \mathrm{E}-17$ & \\
\hline & & & & 2 & 0.0001 & 0.0015 & 0.0008 & 0.026 & $5.25 \mathrm{E}-15$ & \\
\hline & & & & 3 & 0.005 & 0.002 & 0.00125 & 0.13 & 4.01E-15 & $5.81 \mathrm{E}-17$ \\
\hline & 8 & I & 7.7 & 1 & 0.001 & 0.004 & 0.0025 & 0.038 & $1.1 \mathrm{E}-13$ & \\
\hline & & & & 2 & 0.0002 & 0.0065 & 0.00335 & 0.14 & 7.16E-14 & \\
\hline & & & & 3 & 0.0005 & 0.0025 & 0.0015 & 0.08 & $1.12 \mathrm{E}-14$ & \\
\hline & & & & 4 & 0.0001 & 0.0055 & 0.0028 & 0.184 & $3.18 \mathrm{E}-14$ & \\
\hline & & & & 5 & 0.0002 & 0.0065 & 0.00335 & 0.16 & $6.26 \mathrm{E}-14$ & $3.14 \mathrm{E}-14$ \\
\hline & & III & 7.7 & 1 & 0.0005 & 0.0015 & 0.001 & 0.078 & $3.41 \mathrm{E}-15$ & \\
\hline & & & & 2 & 0.0001 & 0.002 & 0.00105 & 0.27 & $1.14 \mathrm{E}-15$ & $1.71 \mathrm{E}-15$ \\
\hline
\end{tabular}



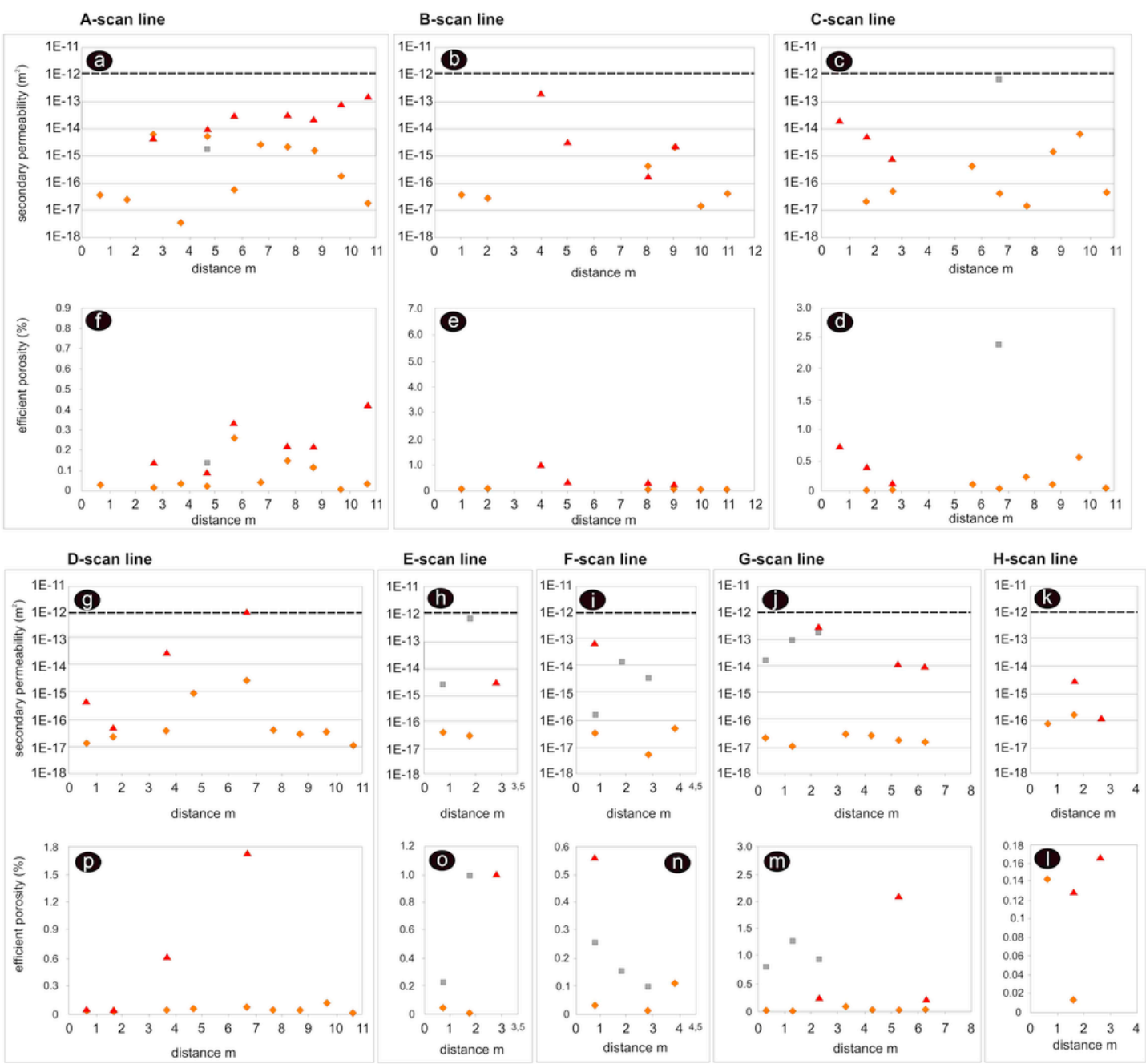

K-scan line
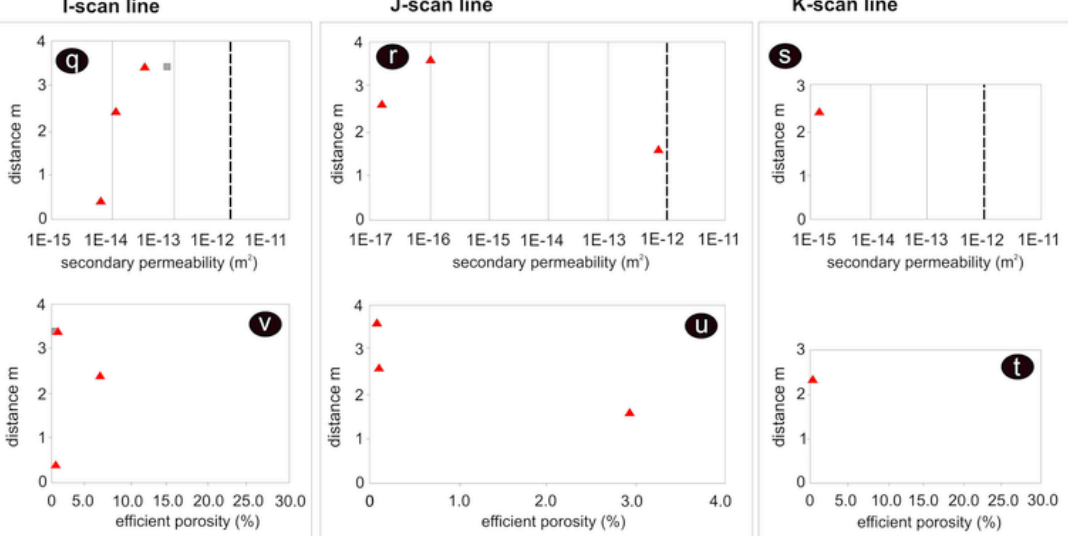

$\Delta 1^{\text {st }}$ faults generation $2^{\text {nd }}$ faults generation $3^{\text {rd }}$ faults generation

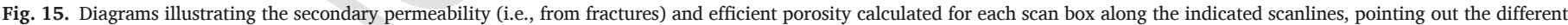
faults generations. Each labelled diagram is discussed in the text to which the reader is addressed for more explanations.

der of tens of centimeters, that are not reasonable to explain as a consequence of a single deformational event. Similarly, those values deriving from transient overpressured fluids forming hydraulic breccias (Fig. $4 \mathrm{~g}$ ) were also cut away. Furthermore, it should be taken into account that explosive hydrothermal brecciation (burst breccias, in Gaweda et al., 2013) as consequence of co-seismic events (Miller et al., 2004; Waldhauser et al., 2012) or exsolution of superheated late-magmatic fluids (Gaweda et al., 2013) are not compatible, in principle, with a laminar flow.
$\mathrm{K}$ values were calculated for the minimum and maximum possible pressure values of fluid inclusion trapping. Maximum pressure (up to $2 \mathrm{Kbar}$ ) corresponds to lithostatic regime whereas minimum pressure implies hydrostatic or sub-hydrostatic pressure. During faults activity and fluid flow, pressure likely oscillated between hydrostatic and lithostatic regime, as evidenced by hydraulic fracturing events. Thus, $\mathrm{K}$ values at the maximum pressure are the lowest and probably occurred when the system was pressurized whereas maximum $\mathrm{K}$ values occur at 

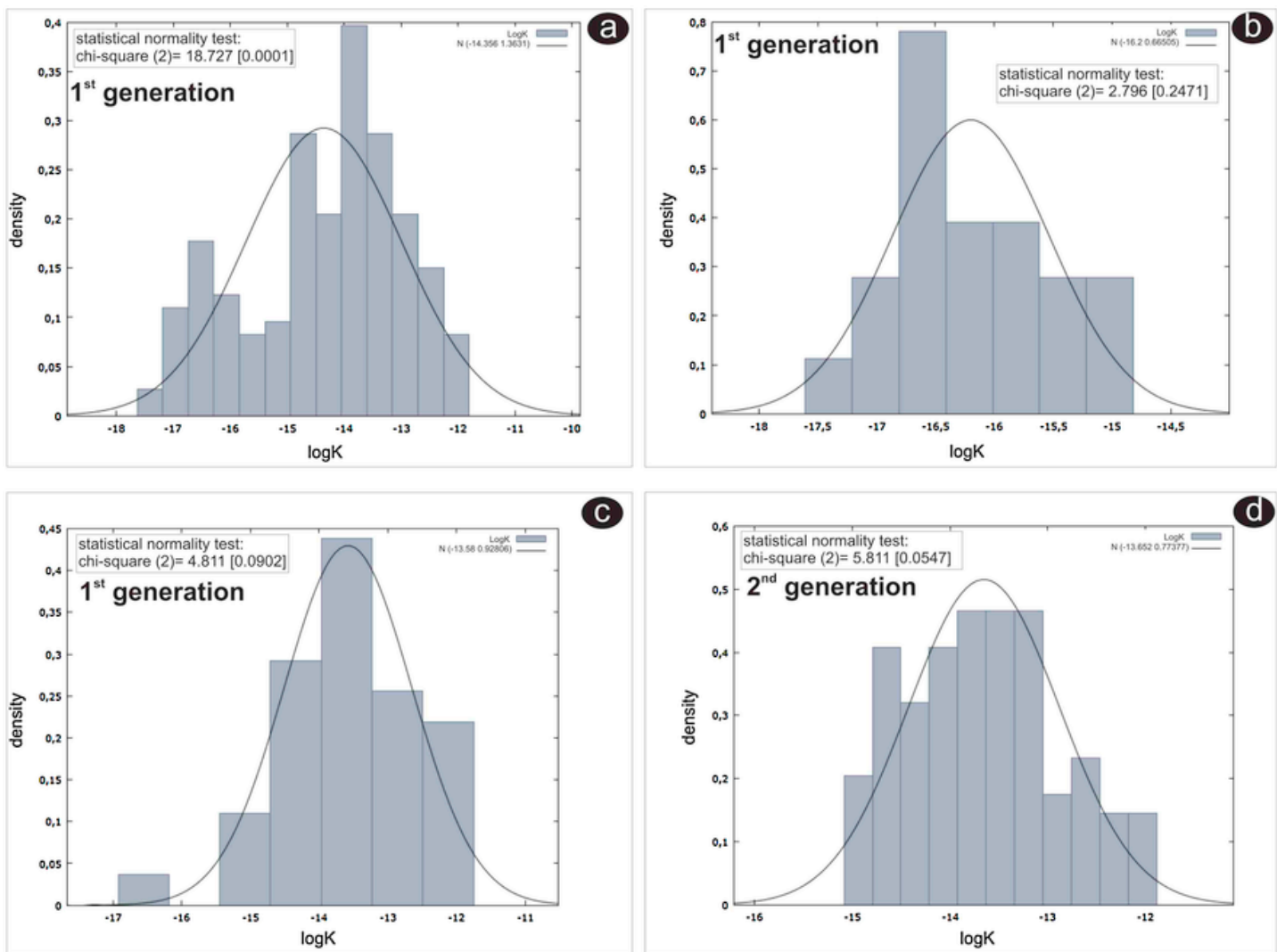

C
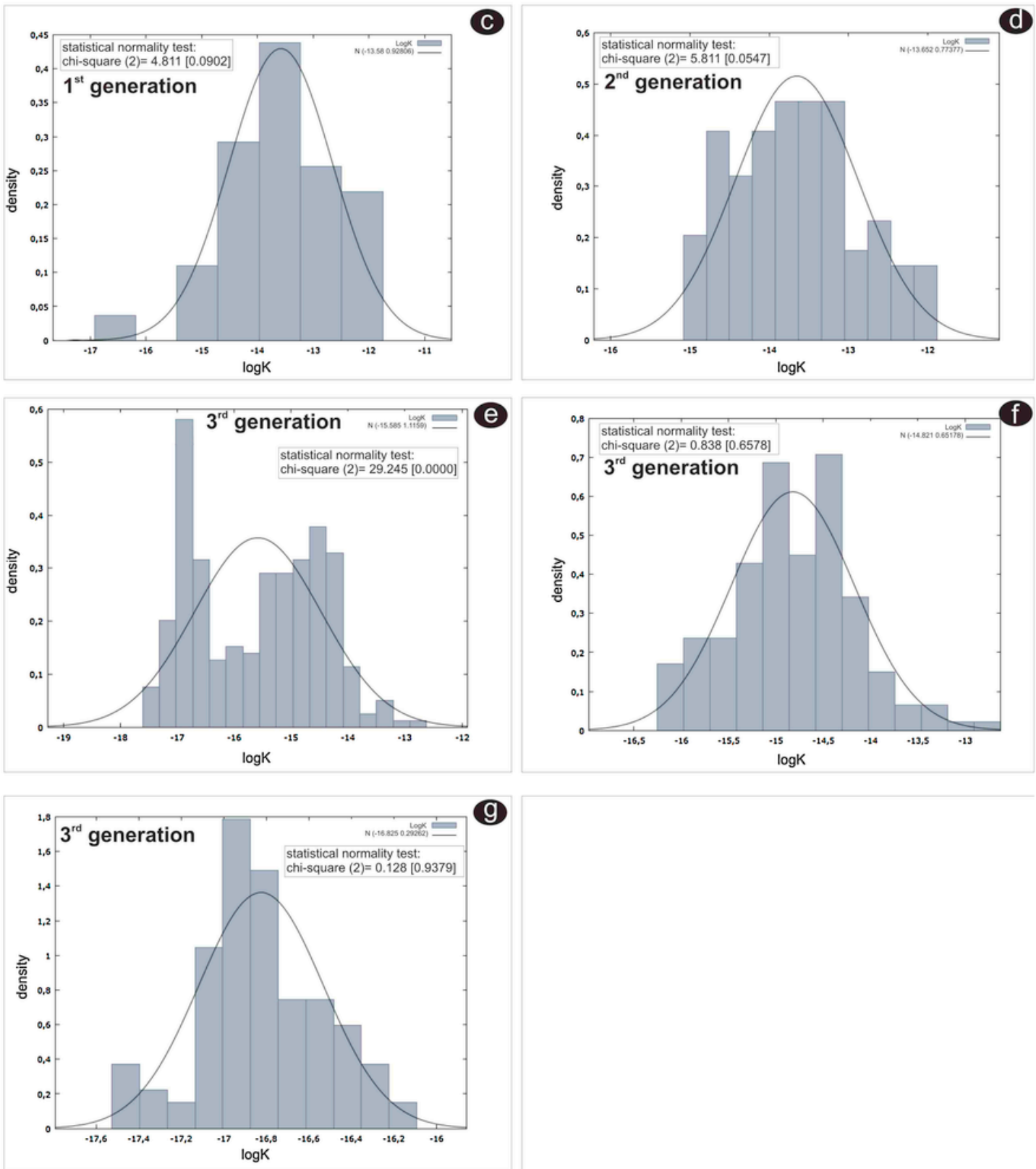

Fig. 16. Diagrams illustrating the statistical distribution of the permeability values for the different faults generation. 
T20

varues of viscosity, density, permeability and hydraulic conductivity for each faults generation. Low pressure and high pressure refer to variables calculated at minimum (i.e., homogenization) and maximum trapping conditions, respectively.

\begin{tabular}{|c|c|c|c|c|c|c|c|c|c|c|c|c|}
\hline \multirow{3}{*}{$\begin{array}{l}\text { FAULTS } \\
\text { GENERATION }\end{array}$} & \multirow{3}{*}{$\begin{array}{l}\begin{array}{l}\text { Fluid inclusion } \\
\text { type }\end{array} \\
\text { L }\end{array}$} & \multirow{3}{*}{$\begin{array}{l}\begin{array}{l}\text { DENSITY }(\mathrm{g} / \\
\left.\mathrm{m}^{3}\right)\end{array} \\
661 / 889\end{array}$} & \multicolumn{4}{|c|}{$\eta$ VISCOSITY $\left(\mu \mathrm{Pa}^{*} \mathrm{~s}\right)$} & \multicolumn{2}{|c|}{ K PFRMEABLLITY $\left(\mathrm{m}^{2}\right)$} & \multicolumn{4}{|c|}{ K HYDRAULIC CONDUCTIVITY (m/s) } \\
\hline & & & \multicolumn{2}{|c|}{ low pressure range } & \multicolumn{2}{|c|}{ high pressure range } & \multirow{2}{*}{$\begin{array}{l}\max \\
5.00 \mathrm{E}-14\end{array}$} & \multirow{2}{*}{$\begin{array}{l}\min \\
5.00 \mathrm{E}-16\end{array}$} & \multicolumn{2}{|c|}{ low pressure range } & \multicolumn{2}{|c|}{ high pressure range } \\
\hline & & & $3.29 \mathrm{E}+01$ & $5.91 \mathrm{E}+01$ & $7.06 \mathrm{E}+01$ & $1.24 \mathrm{E}+02$ & & & $1.00 \mathrm{E}-09$ & $8.26 \mathrm{E}-12$ & 4.7E-10 & $3.9 \mathrm{E}-12$ \\
\hline & $\mathrm{s}$ & $1105 / 1142$ & $3.88 \mathrm{E}+01$ & $2.40 \mathrm{E}+02$ & $1.91 \mathrm{E}+02$ & $2.78 \mathrm{E}+02$ & $5.00 \mathrm{E}-14$ & $5.00 \mathrm{E}-16$ & $8.52 \mathrm{E}-10$ & $2.04 \mathrm{E}-12$ & $1.7 \mathrm{E}-10$ & $1.8 \mathrm{E}-12$ \\
\hline \multirow[t]{2}{*}{ 2nd } & $\mathrm{L}$ & $661 / 889$ & $3.29 \mathrm{E}+01$ & $5.91 \mathrm{E}+01$ & $7.06 \mathrm{E}+01$ & $1.24 \mathrm{E}+02$ & $5.00 \mathrm{E}-13$ & $5.00 \mathrm{E}-14$ & $1.54 \mathrm{E}-08$ & $1.76 \mathrm{E}-09$ & 7.2E-09 & $8.4 \mathrm{E}-10$ \\
\hline & $\mathrm{s}$ & $1105 / 1142$ & $3.88 \mathrm{E}+01$ & $2.40 \mathrm{E}+02$ & $1.91 \mathrm{E}+02$ & $2.78 \mathrm{E}+02$ & $5.00 \mathrm{E}-13$ & $5.00 \mathrm{E}-14$ & $1.31 \mathrm{E}-08$ & $4.34 \mathrm{E}-10$ & $2.7 \mathrm{E}-09$ & $3.8 \mathrm{E}-10$ \\
\hline \multirow[t]{2}{*}{ 3rd } & $\mathrm{L}$ & $777 / 1029$ & $2.72 \mathrm{E}+01$ & $4.81 \mathrm{E}+01$ & $9.56 \mathrm{E}+01$ & $1.61 \mathrm{E}+02$ & $5.00 \mathrm{E}-15$ & $5.00 \mathrm{E}-17$ & $1.43 \mathrm{E}-10$ & $1.07 \mathrm{E}-12$ & $4.1 \mathrm{E}-11$ & $3.2 \mathrm{E}-13$ \\
\hline & $\mathrm{s}$ & $1100 / 1110$ & $1.98 \mathrm{E}+02$ & $2.26 \mathrm{E}+02$ & $2.22 \mathrm{E}+02$ & $2.31 \mathrm{E}+02$ & $5.00 \mathrm{E}-15$ & $5.00 \mathrm{E}-17$ & $2.77 \mathrm{E}-11$ & $2.46 \mathrm{E}-13$ & $2.5 \mathrm{E}-11$ & $2.4 \mathrm{E}-13$ \\
\hline
\end{tabular}


low pressure and are likely characteristic of the conditions after the depressurization event related to hydro-fracturing.

The maximum and minimum $\mathrm{K}$ values computed from the data of $\mathrm{S}$ inclusions are always lower than the corresponding $\mathrm{K}$ values of $\mathrm{L}$ inclusions in all faults generations. However, the relatively high viscosity of the fluid trapped in S inclusions ( $>200 \mu$ Pa.s) makes this kind of fluid characterized by a limited mobility, suggesting that such fluid was scarcely mobilised in the main fluid flow. Thus, only the K values computed for $\mathrm{L}$ inclusions are considered representative for the dominant $\mathrm{K}$ during the hydrothermal flow.

The validity of the proposed approach finds a confirmation in the $\mathrm{k}$ and $\mathrm{K}$ values from comparable reservoirs in active geothermal systems (Rowland and Sibson, 2004). Moreover, taking in account that the study area is considered as a part of the Larderello geothermal field proxy, it is significant that $\mathrm{k}$ values we have obtained are in the range of those measured within the micaschist hosting the deep reservoir exploited in the Larderello geothermal area, at 3-5 km depth (Cappetti et al., 1995; Romagnoli et al., 2010).

Thus, although the parallel-plate-model has limitations, the results provide reliable estimations. Permeability values beyond the resolution limits of the model can be explained as the contribution of overpressured fluids.

Another positive confirmation derives from the experimental studies conducted on brittle shear zones assisted by fluids, indicating typical values of permeability comprised between $10^{-14}$ and $10^{-16} \mathrm{~m}^{2}$ (Townend and Zoback, 2000; Wibberley and Shimamoto, 2003).

As it regards the obtained viscosity values, these are not directly comparable with those from Larderello field, where exploited fluids are vapour-dominated (Romagnoli et al., 2010). Geothermal fields characterized by saline to hyper-saline fluids are rare: one of these is the Kakkonda geothermal system, where exploited fluids have a comparable viscosity, as described in Yano and Ishido (1996). Finally, it is worth to underline that the resulting hydraulic conductivity estimation, is in line with those already estimated from altered micaschist (Domenico, 1972).

\section{Conclusions}

On the basis of the results obtained in this study, we propose the following protocol of investigation, during the preliminary phases of any geothermal exploration:

a) identifying the analogue exhumed geothermal system of the exploitable area;

b) in the exhumed geothermal area, mineralised key-areas should be chosen, where a detailed structural and kinematic survey can be carried out and reported in a detailed map;

c) mineralized faults and veins distribution at map-scale will indicate the most suitable orientation for the frequency analysis along scan lines;

d) the frequency analysis will be used to calibrate the scan box size and spacing;

e) within each scan box, width and length of each vein will be collected, through field and image analyses;

f) based on the collected data, the parallel-plate model will give permeability values;

g) fluid inclusions data will provide information to estimate trapping temperature and salinity of the circulating geothermal paleo-fluids; from these values, density and viscosity of fluids can be obtained;

h) joining permeability with viscosity and density, the hydraulic conductivity will be gained.

Summing up, in exhumed geothermal systems, the study of the faults-veins array through geometrical and kinematic analyses, inte- grated with fluid inclusions data and numerical modeling (parallel-plate-model equation), can provide reliable data (commonly obtained after drilling) for rock-physical and hydraulic parameters, representing key-values for an evaluation of the geothermal potentiality of any exploitable area.

\section{Uncited references}

Caggianelli et al. (2014), Evans and Powell (2006), Fleury and Deschamps (2008), Holland and Powell (2003), Lonergan et al. (1998), Mongelli et al. (1998), Mongelli and Zito (1991)

\section{Acknowledgments}

The research leading to these results has received funding from the European Community's Seventh Framework Programme under grant agreement No. 608553 (Project IMAGE). We are indebted with Marco Meccheri for his fruitful collaboration during data collection. Giancarlo Molli and an anonymous reviewer helped us to improve the original manuscript with their suggestions and criticisms. Claudio Cecchini supported us with extraordinary meals.

\section{References}

Agosta, F., Alessandroni, M., Antonellini, M., Tondi, E., Giorgioni, M., 2010. From fractures to flow: a field-based quantitative analysis of an outcropping carbonate reservoir. Tectonophysics 490, 197-213.

Alt-Epping, P., Diamond, L.W., Haring, M.O., 2013. Prediction of water?rock interaction and porosity evolution in a granitoid- hosted enhanced geothermal system, using constraints from the $5 \mathrm{~km}$ Basel-1 well. Appl. Geochem. 38, 121-133.

Barberi, F., Brandi, G.P., Giglia, G., Innocenti, F., Marinelli, G., Raggi, R., Ricci, C.A., Squarci, P., Taffi, L., Trevisan, L., 1967. Carta Geologica Dell'Isola d'Elba Alla Scala 1:25.000. E.I.R.A., Firenze.

Barbier, E., 2002. Geothermal energy technology and current status: an overview. Renew Sustain Energy Re. 6, 3-65.

Barchi, M.R., 2010. The Neogene-Quaternary evolution of the Northern Apennines: crustal structure, style of deformation and seismicity. In: In: Beltrando, M., Peccerillo, A., Mattei, M., Conticelli, S., Doglioni, C. (Eds.), The Neogene-Quaternary Evolution of the Northern Apennines: Crustal Structure, Style of Deformation, Seismicity, 36, (Journ. Virt. Explorer, http://dx.doi.org/10.3809/jvirtex.2009.00220 2010).

Bartole, R., 1995. The North Tyrrhenian-Northern Apennines post-collisional system: constraints for a geodynamic model. Terra Nova 7, 7-30.

Batini, F., Brogi, A., Lazzarotto, A., Liotta, D., Pandeli, E., 2003. Geological Features of the Larderello-Travale and Mt. Amiata Geothermal Areas (southern Tuscany, Italy). Episodes 26. 239-244.

Bellani, S., Brogi, A., Lazzarotto, A., Liotta, D., Ranalli, G., 2004. Heat flow, deep temperatures and extensional structures in the Larderello geothermal field (Italy): constraints on geothermal fluid flow. J. Volcanol. Geotherm. Res. 132, 15-29.

Bianco, C., Brogi, A., Caggianelli, A., Giorgetti, G., Liotta, D., Meccheri, M., 2015. HP-LT metamorphism in Elba Island: implications for the geodynamic evolution of the inner Northern Apennines (Italy). J. Geodyn. 91, 13-25.

Bodnar, R.J., Vytik, M.O., 1994. Interpretation of microthermometric data for $\mathrm{H}_{2} \mathrm{O}-\mathrm{NaCl}$ fluid inclusions. In: Vivo, B.D., Frezzotti, M.L. (Eds.), Fluid Inclusions in Minerals: Methods and Applications. Virginia Polytechnic Institute, Blacksburg, pp. 117-130.

Bons, P.D., Elburg, M.A., Gomez-Rivas, E., 2012. A review of the formation of tectonic veins and their microstructures. J. Struct. Geol. 43, 33-62.

Bortolotti, V., Fazzuoli, M., Pandeli, F., Principi, G., Babbini, A., Corti, S., 2001. Geology of central and eastern Elba Island Italy. Ofioliti 26, 97-150.

Bourbiaux, B., Cacas, M.C., Sarda, S., Sabathier, J.C., 1998. A rapid and efficient methodology to convert fractured reservoir images into a dual-Porosity model. Oil Gas Sci. Technol. - Rev. IFP 6 (53), 785-799.

Brogi, A., Giorgetti, G., 2012. Tectono-metamorphic evolution of the siliciclastic units in the Middle Tuscan Range (inner Northern Apennines): Mg-carpholite bearing quartz veins related to syn-metamorphic syn-orogenic foliation. Tectonophysics 526-529, 167-184.

Brogi, A., Liotta, D., 2008. Highly extended terrains, lateral segmentation of the substratum, and basin development: the Middle-Late Miocene Radicondoli Basin (inner northern Apennines, Italy). Tectonics (TC 5002).

Brogi, A., Lazzarotto, A., Liotta, D., Ranalli, G., 2005. Crustal structures in the geothermal areas of southern Tuscany (Italy): insights from the CROP 18 deep seismic reflection lines. J. Volcanol. Geotherm. Res. 148, 60-80.

Brogi, A., Capezzuoli, E., Buracchi, E., Branca, M., 2012. Tectonic control on travertine and calcareous tufa deposition in a low-temperature geothermal system (Sarteano, Central Italy). J. Geol. Soc. London 169, 461-476.

Brogi, A., Alçiçek, C., Yalçıner, C.C., Capezzuoli, E., Liotta, D., Meccheri, M., Rimondi, V., Ruggieri, G., Gandin, A., Boschi, C., Buyuksara, A., Alçiçek, H., Bulbul, A., Baykara, M.O., Shen, C.-C., 2016. Hydrothermal fluids circulation and travertine deposition in an active tectonic setting: insights from the Kamara geothermal area (western Anatolia, Turkey). Tectonophysics 680, 211-232. 
Brogi, A., 2006. Neogene extension in the Northern Apennines (Italy): insights from the southern part of the Mt: amiata geothermal area. Geodinamica Acta 19, 33-50.

Brogi, A., 2008. Kinematics and geometry of Miocene low-angle detachments and exhumation of the metamorphic units in the hinterland of the Northern Apennines (Italy). J. Struct. Geol. 30, 2-20.

Bucher, K., Frey, M., 1994. Petrogenesis of Metamorphic Rocks. Springer, Verlag, Berlin, 318.

Cacas, M.C., Ledoux, E., de Marsily, G., Barbreau, A., Calmels, P., Gaillard, B., Margritta, R., 1990. Modeling fracture flow with a stochastic discrete fracture network: calibration and validation: 2 . The transport model. AN AGU J. 26, 491-500.

Caggianelli, A., Ranalli, G., Lavecchia, A., Liotta, D., Dini, A., 2014. Post-emplacement thermo-rheological history of a granite intrusion and surrounding rocks: the Monte Capanne pluton, Elba Island, Italy. In: In: Llan-Fúnez, S., Marcos, A., Bastida, F. (Eds.), Deformation Structures and Processes Within the Continental Crust, 394. Geol. Soc., London, Spec. Publ., pp. 129-143.

Calcagnile, G., Panza, G.F., 1981. The main characteristics of the Lithosphere Asthenosphere System in Italy and surrounding regions. Pure Appl. Geophys. 119, 865-879.

Cappetti, G., Parisi, L., Ridolfi, A., Stefani, G., 1995. Fifteen years of reinjection in the Larderello- Valle Secolo area: analysis of the production data. In: Florence, Italy, May 18-31. Proceedings World Geothermal Congress WGC95, 3, pp. 1797-2000.

Carmignani, L., Decandia, F.A., Disperati, L., Fantozzi, P.L., Lazzarotto, A., Liotta, D., Meccheri, M., 1994. Tertiary extensional tectonics in tuscany (Northern apenines, Italy). Tectonophysics 238, 295-315.

Carmignani, L., Decandia, F.A., Disperati, L., Fantozzi, P.L., Lazzarotto, A., Liotta, D., Oggiano, G., 1995. Relationships between the Sardinia-Corsica-Provencal domain and the northern apennines. Terra Nova 7, 128-137.

Cavarretta, G., Gianelli, G., Puxeddu, M., 1993. Hydrothermal and contact metamorphism in the Larderello geothermal field (Italy): a new contribution from San Pompeo2 deep well. In: 4th International Symposium on Water-Rock Interaction. August 29-September 3, 1883, Misasa, Japan. pp. 82-86.

Collettini, C., Holdsworth, R.E., 2004. Fault zone weakening and character of slip along low-angle normal faults: insights from the Zuccale fault Elba, Italy. J. Geol. Soc. London 161, 1039-1051.

Collettini, C., De Paola, N., Goulty, N.R., 2006. Switches in the minimum compressive stress direction induced by overpressure beneath a low-permeability fault zone. Terra Nova 18, 224-231.

Cox, S.F., Knackstedt, M.A., Braun, J., 2001. Principles of Structural Control on Permeability and Fluid Flow in Hydrothermal Systems. (Structural Controls on Ore Genesis) Society of Economic Geologists, 24. 1-24 (Chapter 1).

Cox, S.F., 1999. Deformational controls on the dynamics of fluid flow in mesothermal gold systems. Geol. Soc. London Special Publication 155, 123-140.

Curewitz, D., Karson, J.A., 1997. Structural settings of hydrothermal outflow: fracture permeability maintained by fault propagation and interaction. J. Volcanol. Geotherm. Res. 79, 149-168.

de Dreuzy, J.-R., Davy, P., Bour, O., 2001. Hydraulic properties of two-dimensional random fracture networks following a power law length distribution 1: Effective connectivity. Water Resour. Res. 37, 2065-2078.

de Dreuzy, J.-R., Davy, P., Bour, O., 2001. Hydraulic properties of two-dimensional random fracture networks following a power law length distribution 2: Permeability of networks based on lognormal distribution of apertures. Water Resour. Res. 37, 2079-2095.

de Dreuzy, J.-R., Davy, P., Bour, O., 2002. Hydraulic properties of two-dimensional random fracture networks following a power law length distribution. Water Resour. Res. 38 (12), 1276. http://dx.doi.org/10.1029/2001WR001009.

Della Vedova, B., Bellani, S., Pellis, G., Squarci, P., 2001. Deep temperatures and surface heat fow distribution. In: Vai, G.B., Martini, I.P. (Eds.), Anatomy of an Orogen: The Apennines and Adjacent Mediterranean Basins. Kluwer Academic Publishers, Amsterdam, pp. 65-76.

Dini, A., Innocenti, F., Rocchi, S., Tonarini, S., Westerman, D.S., 2002. The magmatic evolution of the late Miocene laccolith-pluton-dyke granitic complex of Elba Island, Italy. Geol. Mag. 139, 257-279.

Dini, A., Gianelli, G., Puxeddu, M., Ruggieri, G., 2005. Origin and evolution of Pliocene-Pleistocene granites from the Larderello geothermal field (Tuscan Magmatic Province, Italy). Lithos 81, 1-31.

Dini, A., Mazzarini, F., Musumeci, G., Rocchi, S., 2008. Multiple hydro-fracturing by boron-rich fluids in the late Miocene contact aureole of eastern Elba Island (Tuscany Italy). Terra Nova 20, 318-326.

Dini, A., 2003. Ore deposits, industrial minerals and geothermal resources. Per. Mineral. $72,41-52$

Domenico, P.A., 1972. Concepts and Models in Groundwater Hydrology. McGraw-Hill, New York. (405 pages)

Driesner, T., Heinrich, C.A., 2007. The system H2O-NaCl. Part I. Correlation formulae for phase relations in pressure-temperature-composition space from 0 to $1000{ }^{\circ} \mathrm{C}, 1-5000$ bar, and 0 to $1 \mathrm{XNaCl}$. Geochim. Cosmochim. Acta 71, 4880-4901.

Driesner, T., 2007. The System H2O-NaCl. Part II. Correlations for molar volume, enthalpy, and isobaric heat capacity from 0 to 1000 _C $1-5000 \mathrm{bar}$, and $0-1 \mathrm{XNaCl}$. Geochim. Cosmochim. Acta 71, 4902-4919.

Dubacq, B., Bickle, M.J., Evans, K.A., 2013. An activity model for phase equilibria in the $\mathrm{H}_{2} \mathrm{O}-\mathrm{CO}_{2}-\mathrm{NaCl}$ system. Geoch. Cosmochim. Acta 110, 229-252.

Duranti, S., Palmeri, R., Pertusati, P.C., Ricci, C.A., 1992. Geological evolution andmetamorphic petrology of the basal sequence of eastern Elba (complex II). Acta Vulcanol. 2, 213-229.

Evans, K., Powell, R., 2006. A method for activity calculations in saline and mixed solvent solutions at elevated temperature and pressure: a framework for geological phase equilibria calculations. Geochim. Cosmochim. Acta 70 (22), 5488-5506.

Faulkner, D.R., Jackson, C.A.L., Lunn, R.J., Schlische, R.W., Shipton, Z.K., Wibberley, C.A.J., Withjack, M.O., 2010. A review of recent developments concerning the structure, mechanisms and fluid flow properties of fault zones. J. Struct. Geol. 32, 1557-1575.
Fleury, M., Deschamps, H., 2008. Electrical conductivity and viscosity of aqueous $\mathrm{NaCl}$ solutions with dissolved $\mathrm{CO}_{2}$ - institut français du Pétrole (IFP), petrophysics department, 92852 rueil-Malmaison, France. J. Chem. Eng Data 53 (11), 2505-2509.

Fyfe, W.S., 1987. Tectonics, fluids and ore deposits: mobilisation and remobilitation. Ore Geol. Rev. 2, 21-36.

Gale, J.E., 1982. Assessing the permeability characteristics of fractured rock. Geol. Soc. Am. Spec. Pap. 189, 163-182. http://dx.doi.org/10.1130/SPE189-p163.

Garfagnoli, F., Menna, F., Pandeli, E., Principi, G., 2005. The porto azzurro unit (Mt calamita promontory, South-Eastern Eelba Island, Tuscany): stratigraphic, tectonic and metamorphic evolution. Boll. Soc. Geol. Italy 3, 119-138.

Gaweda, A., Muller, A., Stein, H., Kadziolko-Gawel, M., Mikulski, S., 2013. Age and origin of the tourmaline-rich hydraulic breccias in the Tatra Granite, Western Carpathians. J. Geosci. 58, 133-148.

Hausegger, S., Kurz, W., Rabitsch, R., Kiechl, E., Broscha, F.J., 2009. Analysis of the internal structure of a carbonate damage zone: implications for the mechanisms of fault breccia formation and fluid flow. J. Struct. Geol. 32, 1349-1362.

Holland, T.J.B., Powell, R., 2003. Activity-composition relations for phases in petrological calculations: an asymmetric multicomponent formulation. Contrib. Mineral. Petrol. 145 (4), 492-501.

Keller, J.V.A., Pialli, G., 1990. Tectonics of the Island of Elba: a reappraisal. Boll. Soc. Geol. Italy $109,413-425$

Kim, Y.S., Sanderson, D., 2010. Inferred fluid flow through fault damage zones based on the observation of stalactites in carbonate caves. J. Struct. Geol. 32, 1305-1316.

Lecumberri-Sanchez, P., Steele-MacInnis, M., Bodnar, R.J., 2012. A numerical model to estimate trapping conditions of fluid inclusions that homogenize by halite disappearance. Geochim. Cosmochim. Acta 92, 14-22.

Leung, C.T.O., Zimmermann, R.W., 2012. Estimating the hydraulic conductivity of two-Dimensional fracture networks using network geometric properties. Transp. Porous Med. 93, 777-797.

Liotta, D., Cernobori, L., Nicolich, R., 1998. Restricted rifting and its coexistence with compressional structures: results from the Crop03 traverse (Northern Apennines Italy). Terra Nova 10, 16-20.

Liotta, D., Brogi, A., Meccheri, M., Dini, A., Bianco, C., Ruggieri, G., 2015. Coexistence of low-angle normal and high-angle strike- to oblique-slip faults during Late Miocene mineralization in eastern Elba Island (Italy). Tectonophysics 660, 17-34.

Lippolt, H., Wernicke, R., Bahr, R., 1995. Paragenetic specularite and adularia (Elba: Italy) - Concordant (U + Th)-He and K-Ar ages. Earth Planet. Sci. Lett. 132, 43-51.

Lisjak, A., Grasselli, G., 2014. A review of discrete modeling techniques for fracturing processes in discontinuous rock masses. J. Rock Mech. Geothecn. Eng. 6, 301-314.

Locardi, E., Nicolich, R., 1992. Geodinamica del Tirreno e dell'Appennino centro-meridionale: la nuova carta della Moho. Mem. Soc. Geol. It. 41, 121-140.

Lonergan, L., Cartwright, J., Laver, R., Staffurth, J., 1998. Polygonal faulting in the Ter tiary of the central North Sea: implications for reservoir geology. Geol. Soc. London Spec. Pub. 127, 191-207.

Long, J.C.S., Witherspoon, P.A., 1985. The relationship of the degree of interconnection to permeability in fracture networks. J. Geophys. Res. B 90, 3087-3098.

Lough, M.F., Lee, S.H., Kamath, J., 1997. A new method to calculate effective permeability of gridblocks used in the simulation of naturally fractured reservoirs. SPE Reservoir Eng. 12 (3), 219-224.

Maineri, C., Benvenuti, M., Costagliola, P., Dini, A., Lattanzi, P., Ruggieri, G., Villa, I., 2003. Sericitic alteration at the La Crocetta deposit (Elba Island, Italy): interplay between magmatism, tectonics and hydrothermal activity. Miner. Deposita 38, 67-86.

Mao, S., Duan, Z., 2009. The viscosity of aqueous alkali-Chloride solutions up to $623 \mathrm{~K}$, 1,000 bar, and high ionic strength. Int. J. Thermophys. 30, 1510. http://dx.doi.org/ 10.1007/s10765-009-0646-7.

Martini, I.P., Sagri, M., 1993. Tectono-sedimentary characteristics and the genesis of the recent magmatism of Southern Tuscany and Northern Latium. Per. Mineral. 56, 157-172.

Massonnat, G., Manisse, E., 1994. Fractured reservoir modelling and calculation of equivalent parameters: study of the vertical permeability anisotropy. BCREDP (Elf Aquitaine) 18, 171-209.

Mazzarini, F., Musumeci, G., Cruden, A.R., 2011. Vein development during folding in the upper brittle crust: the case of tourmaline-rich veins of eastern Elba Island northern Tyrrhenian Sea Italy. J. Struct. Geol. 33, 1509-1522.

McCaffrey, K.J.W., Lonergan, L., Wikinson, J.J., 1999. Fractures, Fluid flow and mineralization. Geol. Soc. London Spec. Pub. 155, (325 pages).

Miao, T., Yu, B., Duan, Y., Fang, Q., 2015. A fractal analysis of permeability for fractured rocks. Int. J. Heat Mass Transfer 81, 75-80.

Miller, S.A., Collettini, C., Chiaraluce, L., Cocco, M., Barchi, M., Kaus, B.J.P., 2004. Aftershocks driven by a high- pressure $\mathrm{CO}^{2}$ source at depth. Nature $427,724-727$.

Milsch, H., Hofmann, H., Blocher, G., 2016. An experimental and numerical evaluation of continuous fracture permeability measurements during effective pressure cycles. Int. J.. Rock Mech. Min. Sc. 89, 109-115.

Min, K.-B., Jing, L., Stephansson, O., 2004. Determining the equivalent permeability tensor for fractured rock masses suing a stochastic REV approach: method and application to the field data from Sellafield. UK. Hydrogeol. J. 12, 497-510.

Molli, G., 2008. Northern Apennine-Corsica Orogenic System: an Updated Overview, 298. Geological Society London Special Publications, 413-442.

Mon-

gell

and

Zito

1991. F. Mongelli, G. Zito, Flusso Di Calore Nella RegioneToscana. Studi Geologici Camerti Spec, 1, 199191-98.

Mongelli, F., Palumbo, F., Puxeddu, M., Villa, I.M., Zito, G., 1998. Interpretation of the geothermal anomaly of Larderello Italy. Mem. Soc. Geol. Ital. 52, 305-318.

Musumeci, G., Mazzarini, F., Tiepolo, M., Di Vincenzo, G., 2011. U-Pb and 40Ar-39Ar geochronology of Palaeozoic units in the Northern Apennines: determining protolith age and alpine evolution using the Calamita Schist and Ortano Porphyroids. Geol. J. 46, 288-310. 
Nicholl, M.J., Rajaram, H., Glass, R.J., Detwiler, R., 1999. Saturated flow in a single fracture: evaluation of the Reynolds equation in measured aperture fields. Water Resour. Res. 35 (11), 3361-3373.

Odling, N.E., 1992. Network properties of a two-dimensional natural fracture pattern. Pure Appl. Geophys. 138, 95-114.

Oliver, N., Bons, P., 2001. Mechanisms of fluid flow and fluid-rock interaction in fossil metamorphic hydrothermal systems inferred from vein-wallrock patterns, geometry and microstructure. Geofluids 1, 137-162.

Peccerillo, A., 2003. Plio-quaternary magmatism in Italy. Episodes 26, 222-226.

Pertusati, P.C., Raggi, G., Ricci, C.A., Duranti, S., Palmeri, R., 1993. Evoluzione post- collisionale dell'Elba centro-orientale. Mem. Soc. Geol. Ital. 49, 297-312.

Peters, E.J., 2012. Advanced Petrophysics: 1 Geology, Porosity, Absolute Permeability, Heterogeneity, and Geostatistics. Live Oak Book Company, Polo Alto. CA. (p. 238).

Polak, A., Elsworth, D., Yasuhara, A., Grader, A.S., Halleck, P.M., 2003. Permeability reduction of a natural fracture under net dissolution by hydrothermal fluids. Geophys. Res. Lett. 30, 1-4.

Preisig, G., Eberhardt Egischig, V., Roche, V., Van Der Baan, M., Valley, B., Kaiser, P.K., Duff, D., Lowther, R., 2015. Development of connected permeability in massive crystalline rocks through hydraulic fracture propagation and shearing accompanying fluid injection. Geofluids 15, 321-337.

Puxeddu, M., 1984. Structure and late Cenozoic evolution of the upper lithosphere in southwest Tuscany (Italy). Tectonophysics 101, 357-382.

Rimondi, V., Fregola, R.A., Ruggieri, G., Zucchi, M., Chiarantini, L., Orlando, A., Brogi, A., Liotta, D., 2015. Investigating fossil geothermal systems: the case of Elba Island (Tuscany, Italy). Rend. Online Soc. Geol. It. (ISSN: 2035-8008), suppl. n. 2 al vol. 35, pp. 413. Congresso congiunto SIMP-SGI-So.Ge.I.-AIV, Firenze, 2-4 September 2015.

Rimondi, V., Ruggieri, G., Boschi, C., Brogi, A., Dini, A., Fregola, R.A., Chiarantini, L., Liotta, D., Orlando, D., Zucchi, M., 2015. Fluid inclusion and isotopic studies in the eastern Elba Island (Italy) exhumed geothermal system. Part 1: The Calamita Peninsula. In: Manzella, A., Nardini (Eds.), Abstract Book IMAGE Mid-Term Conference. pp. 84, EDIZIONI CNR ISBN 9788879580267. IMAGE Mid-Term Conference, Pisa, 12-13 October 2015.

Roedder, E., 1984. Fluid Inclusions. Mineralogical Society of America, Reviews in Mineralogy, 12. (p. 644).

Romagnoli, P., Arias, A., Barelli, A., Cei, M., Casini, M., 2010. An updated numerical model of the Larderello-Travale geothermal system, Italy. Geothermics 39, 292-313.

Rossetti, F., Faccenna, C., Jolivet, L., Goffé, B., Funiciello, R., 2002. Structural signature and exhumation P-T-t paths of the blueschist units exposed in the interior of the Northern Apennine chain, tectonic implications. Boll. Soc. Geol. Ital. 1, 829-842.

Rowland, J.V., Sibson, R.H., 2004. Structural controls on hydrothermal flow in a segmented rift system Taupo Volcanic Zone, New Zealand. Geofluids 4, 259-283.

Serri, G., Innocenti, F., Manetti, P., 1993. Geochemical and petrological evidence of the subduction of delaminated Adriatic continental lithosphere in the genesis of the Neogene-Quaternary magmatism of central Italy. Tectonophysics 223, 117-147.

Shepherd, T.J., Rankin, A.H., Alderton, D.H.M., 1985. A Practical Guide to Fluid Inclusion Studies. Blackie, 239.

Sibson, R.H., 1987. Earthquake rupturing as a mineralising agent in hydrothermal systems. Geology 15, 701-704.

Sibson, R.H., 2000. Fluid involvement in normal faulting. In: In: Cello, G., Tondi, E. (Eds.), The Resolution of Geological Analysis and Models for Earthquake Faulting Studies. J. Geodyn, 29, pp. 469-499.

Sirevaag, H., Jacobs, J., Ksienzyk, A.K., Rocchi, S., Paoli Jørgensen, G.H., Košler, J., 2016. From Gondwana to Europe: the journey of Elba Island (Italy) as recorded by
$\mathrm{U}$ ? $\mathrm{Pb}$ detrital zircon ages of Paleozoic metasedimentary rocks. Gondwana Res. 38, 273-288.

Smith, S.A.F., Collettini, C., Holdsworth, R.E., 2008. Recognizing the seismic cycle along ancient faults: $\mathrm{CO} 2$-induced fluidization of breccias in the footwall of a sealing low-angle normal fault. J. Struct. Geol. 30, 1034-1046.

Smith, S.A.F., Holdsworth, R.E., Collettini, C., 2011. Interactions between low-angle normal faults and plutonism in the upper crust: insights from the Island of Elba: italy. Geol. Soc. Am. Bull. 123, 329-346.

Steele-MacInnis, M., Lecumberri-Sanchez, P., Bodnar, R.J., 2012. HokieFlincs_H $\mathrm{H}_{2} \mathrm{O}-\mathrm{NaCl}$ : a Microsoft Excel spreadsheet for interpreting microthermometric data from fluid inclusions based on the PVTX properties of H2O-NaCl. Comput. Geosci. 49, 334-337.

Stober, I., Bucher, K., 2007. Hydraulic properties of the crystalline basement. Hydrol. J. 15, 213-224.

Stober, I., Bucher, K., 2014. Hydraulic and hydrochemical properties of deep sedimentary aquifers of the Upper Rhine Graben, Europe. Geofluids 15, 464-482.

Stober, I., Bucher, K., 2015. Hydraulic conductivity of fractured upper crust: insights from hydraulic tests in boreholes and fluid-rock interaction in crystalline basement rocks. Geofluids 15, 161-178. http://dx.doi.org/10.1111/gfl.12104.

Townend, J., Zoback, M.D., 2000. How faulting keeps the crust strong. Geology 28 (5) 399-402.

Trevisan, L., 1950. L'Elba orientale e la sua tettonica di scivolamento per gravità. Mem. Ist. Geol. Univ. Padova 16, 1-30.

Uysal, I.T., Feng, Y., Zhao, J., Isik, V., Nuriel, P., Golding, S., 2009. Hydrothermal $\mathrm{CO}_{2}$ degassing in seismically active zones during the late Quaternary. Chem. Geol. 265, 442-454.

Uysal, I.T., Feng, Y.X., Zhaob, J.X., Bolharb, R., Issik, V., Baublysd, K.A., Yagob, A., Golding, S.D., 2011. Seismic cycles recorded in late Quaternary calcite veins: geochronological, geochemical and microstructural evidence. Earth Planet. Sci. Lett. 303, 84-96.

Viti, C., Brogi, A., Liotta, D., Mugnaioli, E., Spiess, R., Dini, A., Zucchi, M., Vannuccini, G., 2016. Seismic slip recorded in tourmaline fault mirrors from Elba Island (Italy). J. Struct. Geol. 86, 1-12.

Waldhauser, F., Schaff, D.P., Diehl, T., Engdahl, E.R., 2012. Splay faults imaged by fluid-driven aftershocks of the $2004 \mathrm{M}_{\mathrm{w}} 9.2$ Sumatra-Andaman earthquake. Geology 40, 243-246.

Westerman, D.S., Dini, A., Innocenti, F., Rocchi, S., 2004. Rise and fall of a nested christmas-tree laccolith complex, elba island, Italy. In C. breitkreuz and N. petford (eds.), physical geology of high-Level magmatic systems. Geol. Soc. London Spec. Publ. 234, 195-213.

Wibberley, C.A.J., Shimamoto, J., 2003. Internal structure and permeability of major strike-slip fault zones: the Median Tectonic Line in Mie Prefecture, Southwest Japan. J. Struct. Geol. 25, 59-78.

Yano, Y., Ishido, T., 1996. Numerical investigation of pressure transient responses of a well penetrating a deep geothermal reservoir at super-critical conditions, proceedings. In: Twenty-First Workshop on Geothermal Reservoir Engineering. Stanford University. Stanford. California, January 22-24, SGP-TR-151.

Zimmerman, R.W., Bodarsson, G.S., 1996. Hydraulic conductivity of rock fractures. Transport Porous Media 23, 1-30.

Zucchi, M., Rimondi, V., Liotta, D., Brogi, A, Ruggieri, G., Caggianelli, A., Montegrossi G., Dini, A., 2016. Geological structures, HT-fluids flow and permeability in the exhumed geothermal system of eastern Elba Island (Italy): the case of Cala Stagnone. Rend. Online Soc. Geol. It. (ISSN: 2035-8008), suppl. n. 1 al vol. 40, pp. 141. 88(Congresso Società Geologica Italiana, Napoli, 7-9 September 2016. 